\title{
Equal Access to Education: An Evaluation of the Roma Teaching Assistant Program in Serbia
}

\author{
MARIANNA BATTAGLIA $^{\mathrm{a}}$ and LARA LEBEDINSKI ${ }^{\mathrm{b},{ }^{*}}$ \\ ${ }^{\text {a }}$ University of Alicante, Spain \\ ${ }^{\mathrm{b}}$ Foundation for the Advancement of Economics, Beograd, Serbia
}

\begin{abstract}
Summary. - This paper investigates the effects of a remedial education program — the Roma Teaching Assistant Program — targeting the socially excluded Roma minority in Serbia. By using first-hand collected data, we find evidence that children exposed to the program went more to school. We do not find an effect on dropouts or marks for all grades. An examination of heterogeneous effects suggests that children in the first grade benefited more from the program as compared to their older peers through lower dropouts and better marks. Overall, our results suggest that well-targeted remedial education programs can boost outcomes of low performers.

(c) 2015 Elsevier Ltd. All rights reserved.
\end{abstract}

Key words - primary education, remedial education, Roma, ethnic minority, absences, dropouts

\section{INTRODUCTION}

Roma are mainly located in South Eastern Europe and with a population of approximately six million people they constitute the largest ethnic minority in the continent (Open Society Institute, 2008). ${ }^{1}$ They experience severe social exclusion in terms of high poverty levels (European Union Agency for Fundamental Rights, 2014), low educational attainments (Brueggemann, 2012) ${ }^{2}$ and no participation in the political and cultural life (Kocze, 2012).

Schooling is considered to be a remedy to alleviate poverty and improve living conditions of disadvantaged ethnic or racial groups and to foster their integration: higher enrollment rates and better achievement at school are expected to lead to persistent effects in the labor market and in the reduction of poverty in the long-run. The Roma Teaching Assistant (RTA) Program is the main intervention targeting Roma inclusion in education in South Eastern Europe. Roma assistants - one per school-participate in regular lessons where they provide additional help to Roma pupils who have difficulties in following classes. They organize additional lessons, help them with their homework and assignments and once per week visit to their parents.

The goal of this paper is to evaluate the impact of the RTA Program in the first year of its introduction. ${ }^{3}$ We examine the causal effect of the RTA Program by asking the following three questions. Does the program reduce dropouts? Does the program raise attendance? Does the program improve marks? To answer these questions, we use primary data collected during five months in the Summer-Autumn 2010. We employ two different econometric strategies and their combination. First, we exploit the gradual implementation and the intensity of the program in order to base the evaluation of its impact on a comparison of Early and Late Enrollees. Second, we compare children exposed to the program to older cohorts less exposed to it. There is evidence that all children exposed to the program went on average more to school. We also find evidence that marks improved in mathematics and Serbian for first graders. Higher impacts are obtained in schools with a lower number of Roma. This is especially the case for girls, for whom being in a school with a lower number of Roma turns out to be more favorable. Boys respond to the program with fewer absences in schools with fewer Roma.

Only a handful of studies focus on the issues related to the education of Roma people. These studies investigate topics such as the effects of school segregation and the importance of affirmative actions, the role of preschool, and the Roma/Non Roma achievement gap. In many countries in Central, Eastern, and South-Eastern Europe, Roma pupils are often segregated from Non Roma pupils and unjustifiably placed in schools for mentally disabled children. The attendance of these so-called special schools has a negative effect on educational attainment and on later labor market outcomes (O'Higgins \& Brueggemann, 2014). Thus desegregation policies are necessary and governments have committed to desegregating schools, but their implementation has not been successful (Rostas \& Kostka, 2014). Conversely, affirmative action policies are an important tool for increasing the access to higher education for Roma (Garaz, 2014). ${ }^{4}$ The attendance of preschool has been shown to help to reduce the gap in

\footnotetext{
${ }^{*}$ We would like to thank Tito Boeri, Matz Dahlberg, Eliana La Ferrara, Andreas Madestam, Michele Pellizzari, Petra Thielmann, Vincent Vandenberghe and participants at AMID summer school 2010, Bocconi University 2011 Development Reading Group, Bocconi University PhD seminar 2011, Spring Meeting of the Young Economists 2012, Third International Workshop on Applied Economics of Education 2012, CESifo Economic Studies 2012 conference, IRES UCLouvain seminar series and SOLE conference 2013. We are grateful to the personnel of the Serbian Ministry of Education, especially to Boz̈idar Jovanović and Tünde Kovacs-Cerović, for giving us the authorization for this project and for answering all our questions. We are indebted to Nikola Duvnjak from OSCE for answering all our questions about the pilot phase of the program. This paper is produced as part of the project Actors, Markets, and Institutions in Developing Countries: A micro-empirical approach (AMID), a Marie Curie Initial Training Network (ITN) funded by the European Commission under its Seventh Framework program Contract Number 214705 PITN-GA-2008-214705. Financial support from the Belgian Federal Administration of Scientific Research-SPF Sciences under the grant number TA/00/046 is gratefully acknowledged. Financial support from the Spanish MEC (Ref. ECO2014-58434-P) is gratefully acknowledged. Final revision accepted: June 7, 2015.
} 
cognitive outcomes for Roma children (World Bank, 2012). ${ }^{5}$ Moreover, two interesting studies (Baucal, 2006; Kertesi \& Kezdi, 2011) investigate the Roma/Non Roma gap and find large differences in educational outcomes between Roma and Non Roma. Both studies show that the achievement gap between the two groups decreases when accounting for the lower socio-economical status of Roma. ${ }^{6}$

The principal contribution of this paper is that it adds evidence on short-term effects of remedial education targeting a stigmatized ethnic group. Rigorous evaluations of remedial education programs are rare. Policies targeting low-performing students are generally difficult to evaluate because children with learning difficulties are not randomly assigned to programs. A few studies are able to overcome the identification problem and they find support for the effectiveness of remedial education in the short run (Banerjee, Cole, Duflo, \& Linden, 2007; Hanushek, Kain, \& Rivkin, 2002; Jacob \& Lefgren, 2004; Lavy \& Schlosser, 2005). The RTA Program is different from a standard remedial education intervention because it targets a marginalized group that is widespread believed to be different and cannot be integrated. In this case it would not be enough to offer "only" remedial education, because the program could be ineffective for two reasons. First, an additional Non Roma teacher could have low expectations and could not put in effort. Baucal (2006) in fact shows that in Serbia school teachers have lower expectations from Roma and that they dedicate less time to them thus this mechanism could be especially important in our context. Second, the children could not respond to the program because of expected low returns to education. Jensen (2010) has demonstrated that expected returns do affect the schooling decision. Therefore, the way in which the RTA Program affects both the demand and supply side of education is as follows. On the one hand, children are provided with more teaching time. The intervention alters the inputs in the education production function by providing more instruction time to pupils through teaching assistants. Additionally, negative stereotypes about Roma students could be softened and teachers themselves could be providing more support in learning. This is part of the supply side of education. On the other hand, Roma teaching assistant has the same background as the targeted children and she acts as a role model for them. The role model mechanism can affect preferences for education of both children and parents and is expected to affect the demand for education of the Roma population.

This study also speaks to the literature on programs aiming at improving schooling outcomes of minority communities and the poor. The United States has a long tradition of work on evaluations of school programs targeting disadvantaged groups. A wide range of programs across different stages of the life cycle have been evaluated. Some of the well-known primary school interventions include after-school programs (Lauer, Akiba, Wilkerson, Apthorp, Snow, \& Martin-Glenn, 2006), merit pay for principals, teachers, and students (Fryer, 2010; Podgursky \& Springer, 2007), professional development for teachers (Boyd, Grossman, Lankford, Loeb, \& Wyckoff, 2009), getting parents to be more involved (Domina, 2005), placing disadvantaged students in better schools through desegregation busing (Angrist \& Lang, 2004) or altering the neighborhoods in which they live (Jacob, 2004; Sanbonmatsu, Kling, Duncan, \& Brooks-Gunn, 2006). The evidence on the efficacy of these interventions is mixed: certain programs have left the achievement gap essentially unchanged while others were more successful. This literature thus underscores the importance of rigorous evaluations in order to use the available financial resources in the most efficient way.
An additional contribution of this paper is that we give an accurate overview of the attainments of Roma pupils, for which so far the data were limited, and contrast their achievement to the average Non Roma pupils. Our study is able to examine a wide range of outcomes which have been not examined jointly to this date (such as dropouts and absences) due to limited availability of data. To get a better understanding of the effectiveness of an intervention it is important to understand if and at which margin it is working. Policies that promote school enrollment may not promote learning (Miguel \& Kremer, 2004; Schultz, 2004). We believe that the outcomes we use together with marks give a complete overview of the current state of educational achievements of Roma pupils.

The rest of the paper is organized as follows. Section 2 describes the Serbian context that we are studying. Section 3 summarizes the Roma Teaching Assistant Program and describes our data. Sections 4 explains our empirical strategy and presents our results. Section 5 discusses the findings and concludes.

\section{COUNTRY CONTEXT}

Data on Roma in Serbia are inaccurate and scarce. Surveys often lack information about ethnic identity of the respondents. More importantly, when asked about their ethnicity, some Roma people do not declare themselves as Roma. Most of them consider themselves both Roma and Serbian and the question of nationality allows only one answer.

The official 2011 census counts 147,600 Roma, while estimates put forward a number between 350,000 and 500,000 or approximately $5-7 \%$ of the overall population (Stojanović \& Baucal, 2007). Most Roma live in segregated settlements and have different demographic characteristics from the rest of the population. According to the World Bank Living Standard Measurement Survey (LSMS) 2003-which provides a boosted sample of Roma in Serbia-their households are more numerous than the average household, they have more children and their population is younger. The percentage of male Roma who declare to have worked over the last week is similar to the national average $(69 \%)$. Contrary to men, the participation of women is $34 \%$ and considerably lower than the national average $(53 \%)$. Overall, approximately $60 \%$ of Roma have a consumption below the poverty line and weekly consumption of food per household member is half the national average.

Turning to education, $60 \%$ of Roma younger than 18 years have not completed primary education. In contrast, only $20 \%$ of overall population do not have a primary school diploma. Out of all children of primary school-age, 30\% of Roma do not attend school whereas this is the case for only $1 \%$ of the overall population of primary school-age. Using data from the National Assessment Study conducted with third-grade students, Baucal (2006) finds that after the first three years of school Roma pupils lag 2.2-2.5 years behind the average student. Also, children from Roma ethnic minority performed worse on standardized tests than Non Roma children with the same socio-economic background.

The main barriers of access to education for Roma are absence of documents, financial constraints, parents' low educational background, child labor, discrimination from teachers and pupils and language barriers (Open Society Institute, 2008). In the recent years Serbian schools started enrolling children with incomplete documents, but there is still a minor number of children not able to enroll due to lack of them. According to the law, the local government should 
inform schools and parents that children who reach the school-age in the municipality have to enroll at school. But Roma are often not regularly registered as residents in the municipality and the local government is not able to reach out to them. School books and additional school material are a significant burden for the budget of poor families and the most poor among Roma children do not even own adequate clothing for winter months and live in overcrowded homes where they do not have adequate conditions to pursue their studies. A majority of Roma parents have low educational attainment and this implies that they often cannot help their children with their school work. In addition, some parents attach little value to schooling and education. These reasons together imply that the perceived benefits of going to school are lower than respective costs. Moreover, in some cases Roma children help their parents in their jobs. Also, Roma pupils can face discrimination from teachers and other pupils. There is anecdotal evidence that they are often seated in the last row in classrooms, that teachers do not read their homework and that teachers do not encourage them in their studies. Another problematic issue is that a considerable share of them is sent to special schools. ${ }^{8}$ Finally, in a survey conducted by UNICEF-Multiple Indicator Cluster Survey, 2006 - only $10 \%$ of Roma declare Serbian to be their mother tongue. Children may face difficulties at school due to limited knowledge of Serbian. ${ }^{9}$

\section{ROMA TEACHING ASSISTANT PROGRAM AND DATA}

\section{(a) The Roma Teaching Assistant Program}

The Roma Teaching Assistant Program started as a pilot program implemented by various NGOs in 2002. In 2007 the OSCE took over its coordination and financing. In 2009 the program started to have a nation-wide coverage and it is now under the coordination of the Ministry of Education. In the scholastic year 2009-10, 48 primary schools had a Roma assistant: 22 schools started with the program at different points of time during 2002-07; 26 schools started in 2009. The Ministry expanded the program to other 77 schools starting from November 2010.

Based on when the program started in a school, the schools can be divided in two groups: schools entering the program in September 2009 (Early Enrollees) and schools entering the program in November 2010 (Late Enrollees). The 22 schools, which joined the program during 2002-07, are excluded from our analysis. The selection of these schools was not centralized: they were chosen by NGOs based on the share of Roma pupils. For our analysis we will consider only 26 Early Enrollees and 77 Late Enrollees.

Both schools and potential Roma assistants had to apply to participate in the program. Among 78 schools that applied in 2009, a commission representing the government institutions together with OSCE representatives, chose 26 Early Enrollee schools based on the percentage of Roma students (between $5 \%$ and $40 \%$ ) and preferably, the availability of a preschool program in the school. ${ }^{10}$ The requirements for Roma assistants were knowledge of Romani, secondary school diploma, and experience in working with children. 158 candidates applied for 26 assistant positions. ${ }^{11}$ In 2010 the program was renamed as Education for all and starting with the scholastic year 2010-11 Roma teaching assistants were renamed to pedagogical assistants. In year 2010, 252 schools applied for 77 assistants. Similar to the first round, schools were eligible only if they had between $5 \%$ and $40 \%$ of Roma. The only difference between the two rounds was that in the second round the availability of a preschool program was not considered. The reason is that in 2010-11 pedagogical assistants started to work in 50 kindergartens offering compulsory preschool program. Schools not offering the preschool program could have then been close to kindergartens offering it. The Roma pupil would have been helped by an assistant from her entry in the school anyhow. One could argue that this small change in requirements could lead to a selection bias in the two rounds, but our data do not support this claim. ${ }^{12}$ Selection criteria for now pedagogical assistants remained unchanged and out of the 329 applications for the position, 77 were accepted to work at schools and another 50 were accepted for kindergartens.

Schools got to know that they would receive an assistant in early June. They did not inform parents about the presence of the RTAs. The program did not receive publicity from TV and radio. This leads us to believe that parents were not aware of the existence of the RTA before enrolling their children at school. Data also confirm that Early Enrollees did not attract more Roma students than Late Enrollees in the first year of the program. ${ }^{13}$ There is no selection of children into schools.

Every school received only one assistant. Schools received from the Ministry a description of her duties, but they were free to decide how to allocate the time of the assistant depending on the needs of the school. ${ }^{14}$ Activities at school involve both working during regular classes and after-school work. Work with local communities comprises duties such as collecting information about children who did not enroll or who left school, gathering documents for school enrollment, visiting families, ${ }^{15}$ cooperation with Roma NGOs, etc. The assistants were advised to work mainly with lower grades, especially the first. Their objectives were to ensure that children go to school, to prevent them from dropping out and to help them to succeed at school. In 2009 the Ministry of Education organized a series of seminars with the goal of providing the necessary knowledge and skills to Roma teaching assistants. ${ }^{16}$

\section{(b) Data and trends of the variables}

We use primary data collected during five months in the summer/autumn 2010. School data were not available in a digital format and we visited schools and collected in person data from administrative records. Our dataset contains information on 23 schools (out of 26) among Early Enrollees and 15 schools (out of 77) among Late Enrollees. ${ }^{17}$ Given that the data collection process was costly, our dataset consists only of a subsample of Late Enrollees. We selected 15 Late Enrollee schools according to the following criteria: first, they had to be in the same district of an Early Enrollee school ${ }^{18}$; second, they had to be in a rural/urban municipality as the nearby Early Enrollee school; third, they had to share a similar school size to the nearby Early Enrollee school and finally, a similar percentage of Roma pupils. ${ }^{19}$

Schools are mainly in Belgrade/Central Serbia and in the South/South-Eastern part of the nation, and they are equally distributed in rural and urban areas. ${ }^{20}$ Figure 1 reports the distribution of schools in our sample.

The data set contains information on four scholastic yearsfrom 2006-07 to 2009-10 - for the lower four grades of primary school for 18,268 Roma and Non Roma children. It contains for each year and for each pupil the final mark in mathematics, final mark in Serbian, and number of hours of absences in a year. ${ }^{21}$ The data set contains individual characteristics, such as gender, year of birth, month of birth, and 


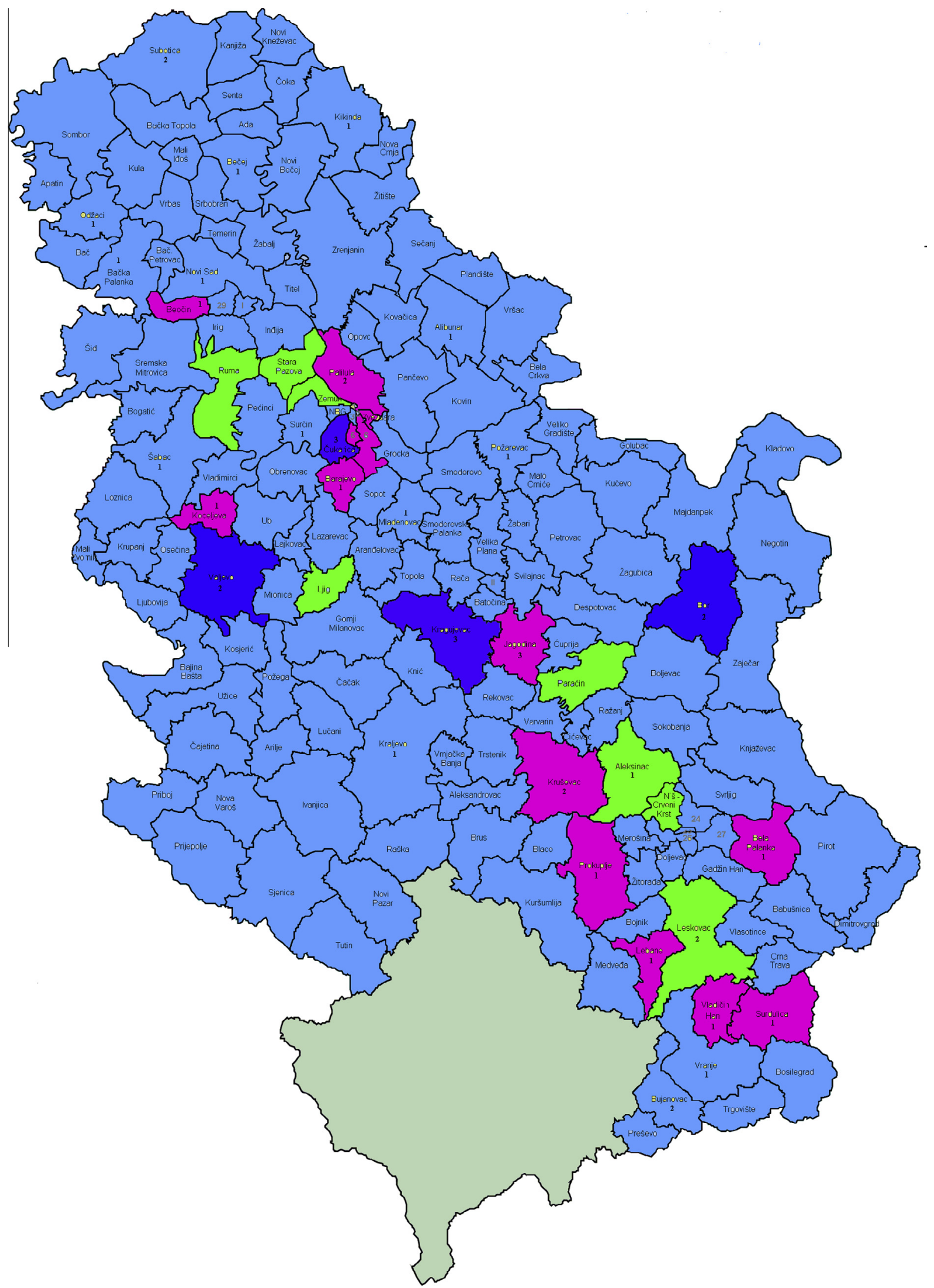

Figure 1. Location of the schools with assistants. This figure reports the distribution of schools in our sample. In pink municipalities there are only Early Enrollee school; in green municipalities there are only Late Enrollee school and in dark blue municipalities there are both Early and Late Enrollee schools. (For interpretation of the references to colour in this figure legend, the reader is referred to the web version of this article.) 
place of birth. ${ }^{22}$ School specific data include school size, number of Roma - in both school and class - and whether the school is in an urban setting.

Roma children Table 1 shows summary statistics of the covariates and main outcomes of interest for Roma children in pre- and treatment years.

In the pre-treatment year the mean characteristics of the schools that were enrolled in the program later (column (2), Table 1) resemble those of the schools that enrolled first (column (1), Table 1). Boys and girls are equally distributed in both groups of schools (roughly $50 \%$ of students in Early Enrollee and 47\% in Late Enrollee schools are female) and pupils were mainly born in the same town where they attend school $(87 \%$ in Early Enrollee and $81 \%$ in Late Enrollee schools). Average pupil's age is 8.7 in both schools. ${ }^{23}$ A fifth of all students in the schools are Roma. The number of Roma per class is roughly $4-5$ children and the class size is 22.161 in Early Enrollees and 23.966 in Late Enrollees. The table shows no statistically significant differences between Early Enrollees and Late Enrollees nor in the students' and schools' characteristics nor in the outcomes of interest. This similarity in covariates between Early Enrollee and Late Enrollee schools is also found in the treatment year, providing support for our claim that Early Enrollees and Late Enrollees are comparable. ${ }^{24}$

By simply comparing average outcomes in the two types of schools, we see that in the last year dropouts almost double in both types of schools and absences increase in both Early Enrollees and Late Enrollees, but they increase by less in Early Enrollee schools. We believe that both the increase in dropouts and in absences is related to the liberalization of the visa regime with the European Union. This regime change induced a considerable number of Roma families to migrate to the EU. Finally, we see a minor improvement in all marks from pre- to treatment year. This effect is larger in Early Enrollees than in Late Enrollees.

Non Roma children. In our main analysis we focus on Roma children because they are the students targeted by the program. We do not aim at quantifying differences in school achievement and attendance between Roma and Non Roma as a consequence of the program and for all our estimations we only use the sample of Roma. Data on Non Roma children are used separately in Section A.4 in the Appendix exclusively to investigate possible spillover effects. Their characteristics are reported here first to provide additional evidence of the comparability of Early and Late Enrollee schools in both pre-treatment and treatment year and second to show substantial differences in education between Roma and Non Roma.

Table 2 shows summary statistics of the covariates and main outcomes of interest for Non Roma children in both years.

No statistically significant differences are found neither in the pre- nor in the treatment year in the pupils' characteristics, providing further support for our claim that Early Enrollees and Late Enrollees are comparable. Moreover, there are no statistically significant differences in the outcomes, excepting the dropout rate, which is close to zero and not problematic in the lower primary school grades. Overall, average outcomes suggest that there are no statistically significant changes for Non Roma children due to the program.

Table 1. Roma-means of covariates and outcomes in pre-treatment and treatment years

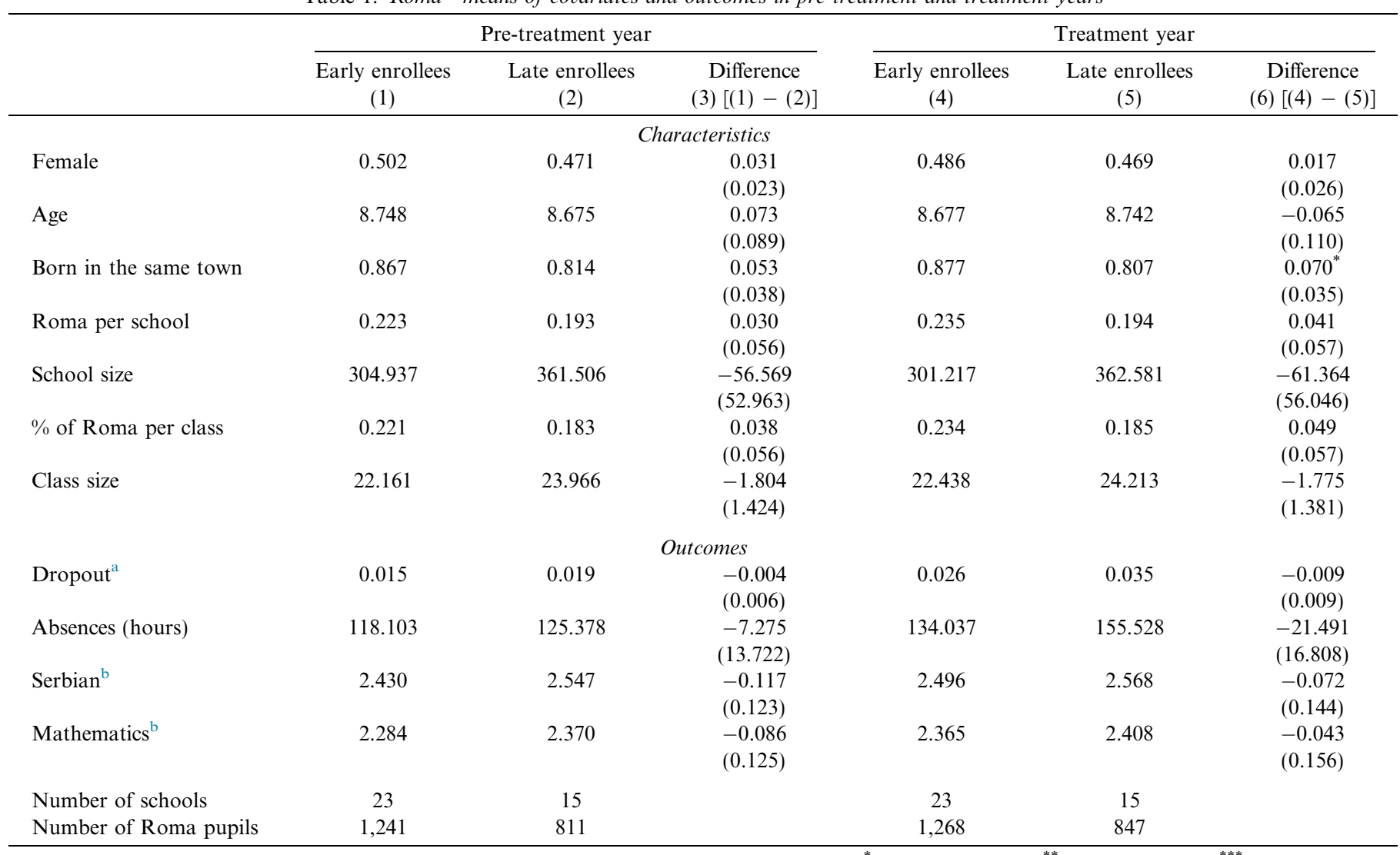

Robust standard errors corrected for clustering at the school level are reported in parentheses: ${ }^{*}$ significant at $10 \%,{ }^{* *}$ significant at $5 \%,{ }^{* * *}$ significant at $1 \%$. ${ }^{a}$ Dropout is equal to 1 if child dropped out of school during the year; otherwise 0 .

${ }^{\mathrm{b}}$ Marks range from 1 (worst) to 5 (best). They are categorical. 
Table 2. Non Roma-Means of covariates and outcomes in pre-treatment and treatment years

\begin{tabular}{|c|c|c|c|c|c|c|}
\hline & \multicolumn{3}{|c|}{ Pre-treatment year } & \multicolumn{3}{|c|}{ Treatment year } \\
\hline & $\begin{array}{l}\text { Early enrollees } \\
\text { (1) }\end{array}$ & $\begin{array}{l}\text { Late enrollees } \\
\text { (2) }\end{array}$ & $\begin{array}{c}\text { Difference } \\
(3)[(1)-(2)]\end{array}$ & $\begin{array}{l}\text { Early enrollees } \\
\text { (4) }\end{array}$ & $\begin{array}{l}\text { Late enrollees } \\
\text { (5) }\end{array}$ & $\begin{array}{c}\text { Difference } \\
(6)[(4)-(5)]\end{array}$ \\
\hline \multicolumn{7}{|c|}{ Characteristics } \\
\hline Female & 0.487 & 0.477 & $\begin{array}{c}0.010 \\
(0.014)\end{array}$ & 0.469 & 0.486 & $\begin{array}{l}-0.017 \\
(0.012)\end{array}$ \\
\hline Age & 8.421 & 8.400 & $\begin{array}{c}0.021 \\
(0.066)\end{array}$ & 8.426 & 8.416 & $\begin{array}{c}0.009 \\
(0.033)\end{array}$ \\
\hline Born in the same town & 0.922 & 0.912 & $\begin{array}{c}0.010 \\
(0.011)\end{array}$ & 0.930 & 0.923 & $\begin{array}{c}0.007 \\
(0.011)\end{array}$ \\
\hline Roma per school & 0.223 & 0.193 & $\begin{array}{c}0.030 \\
(0.056)\end{array}$ & 0.235 & 0.194 & $\begin{array}{c}0.041 \\
(0.057)\end{array}$ \\
\hline School size & 304.937 & 361.506 & $\begin{array}{l}-56.569 \\
(52.963)\end{array}$ & 301.217 & 362.581 & $\begin{array}{l}-61.364 \\
(56.046)\end{array}$ \\
\hline$\%$ of Roma per class & 0.221 & 0.183 & $\begin{array}{c}0.038 \\
(0.056)\end{array}$ & 0.234 & 0.185 & $\begin{array}{c}0.049 \\
(0.057)\end{array}$ \\
\hline Class size & 22.161 & 23.966 & $\begin{array}{l}-1.804 \\
(1.424)\end{array}$ & 22.438 & 24.213 & $\begin{array}{l}-1.775 \\
(1.381)\end{array}$ \\
\hline \multicolumn{7}{|c|}{ Outcomes } \\
\hline Dropout $^{\mathrm{a}}$ & 0.001 & 0.0006 & $\begin{array}{c}0.0004 \\
(0.0006)\end{array}$ & 0.001 & 0.000 & $\begin{array}{c}0.001^{* *} \\
(0.0005)\end{array}$ \\
\hline Absences (hours) & 39.159 & 36.231 & $\begin{array}{l}2.938 \\
(2.535)\end{array}$ & 42.549 & 40.276 & $\begin{array}{c}2.273 \\
(2.743)\end{array}$ \\
\hline Serbian $^{\mathrm{b}}$ & 4.396 & 4.328 & $\begin{array}{c}0.068 \\
(0.070)\end{array}$ & 4.434 & 4.339 & $\begin{array}{c}0.094 \\
(0.072)\end{array}$ \\
\hline Mathematics $^{\mathrm{b}}$ & 4.255 & 4.179 & $\begin{array}{c}0.076 \\
(0.080)\end{array}$ & 4.296 & 4.208 & $\begin{array}{c}0.088 \\
(0.081)\end{array}$ \\
\hline Number of schools & 23 & 15 & & 23 & 15 & \\
\hline Number of Non Roma pupils & 4,303 & 3,374 & & 4,122 & 3,514 & \\
\hline
\end{tabular}

Robust standard errors corrected for clustering at the school level are reported in parentheses: ${ }^{*}$ significant at $10 \%,{ }^{* *}$ significant at $5 \%,{ }^{* * *}$ significant at $1 \%$.

${ }^{a}$ Dropout is equal to 1 if child dropped out of school during the year; otherwise 0 .

${ }^{\mathrm{b}}$ Marks range from 1 (worst) to 5 (best). They are categorical.

Comparison of Roma and Non Roma children. Tables 1 and 2 together show that the differences in dropouts, absences, and marks between Roma and Non Roma children are striking. Three important aspects need to be stressed when comparing them. First, dropouts are almost exclusively of Roma children. Moreover, Roma children are absent from school approximately three to four times more than Non Roma children. Lastly, on a grading scale of 1 to 5, the difference of almost two marks between Roma and Non Roma pupils in Serbian and mathematics is substantial. These differences apply to both genders. However, when we look more deeply into the data we observe that among Roma, although girls perform better at school than boys ${ }^{25}$ (and differences by gender are statistically significant), their dropouts and absences are higher. ${ }^{26}$ There are indeed additional aspects we need to take into account and that explains why in our analysis we also investigate whether the impact of the intervention differs by gender. First, an extensive literature suggests that ethnicity exacerbates gender-biased divisions (and vice versa) and that intersection of gender and ethnicity is associated with systematic outcome disparities across groups, especially in human capital, with consequences in the long-term (Taş, Reimo, \& Orlando, 2014). Second, female Roma have, on average, a lower educational level, spend fewer years in school, and are more likely to drop out from school than their male counterparts (Cukrowska \& Kocze, 2013). Among Roma, traditional gender roles are clearly defined: girls marry at a young age and are expected to take care of children and home. They more frequently stay out of the labor market or work in informal employment (Cukrowska \& Kocze, 2013). The benefits of investing in education in the case of girls are perceived as low. Different impacts by gender of an educational program can be expected. ${ }^{27}$

\section{ECONOMETRIC STRATEGY}

We want to examine the impact of the Roma Teaching Assistant Program in the first year of its implementation on dropouts, attendance, and marks of Roma pupils. In the following analysis we therefore use only data on Roma children. We exploit the gradual implementation of the program. Our treatment group consists of schools which started to implement the program in September 2009 (Early Enrollees), whereas the control group is a subsample of schools which got the assistants starting from November 2010 (Late Enrollees). We argue that the selection of schools to enter the program earlier/later can be treated "as if random" for several reasons. First, the selection criteria remained almost the same in both rounds. ${ }^{28}$ Second, one could argue that schools applying in the first round were more motivated, but schools which applied in the first year could also apply in the second year. However, some schools which applied in 2009 did not apply anymore in the year after. ${ }^{29}$ Thus, if they really were more motivated and of better quality, it is hard to understand why they did not want to be part of the program anymore in 2010. Third, we do know that observable characteristics do not differ between schools applying in the first year and 
Table 3. Average treatment approach

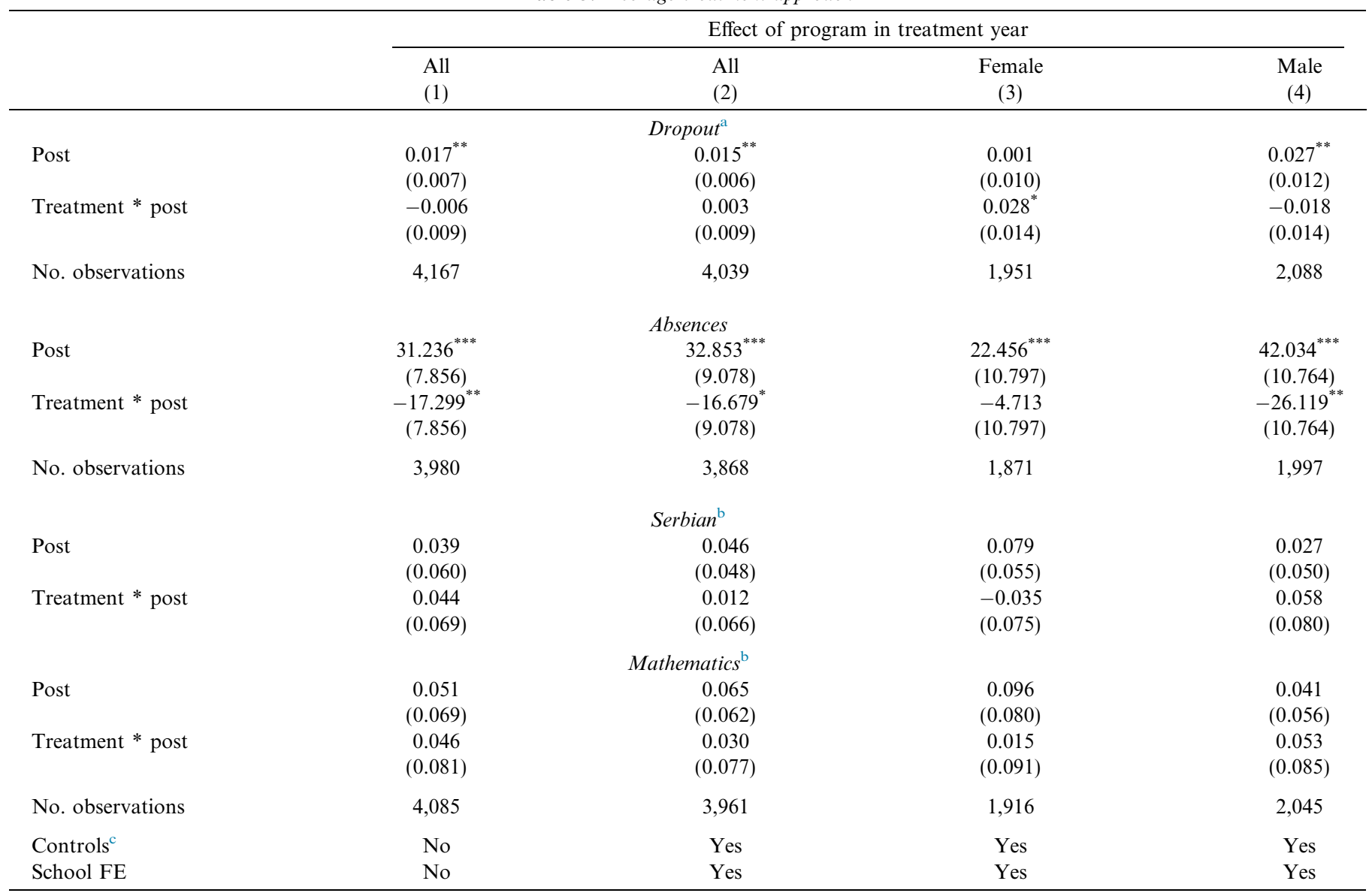

This table reports the effect of the program on dropouts, absences and Serbian and mathematics. Robust standard errors corrected for clustering at the school level are reported in parentheses: ${ }^{*}$ significant at $10 \%,{ }^{* *}$ significant at $5 \%,{ }^{* * *}$ significant at $1 \%$.

${ }^{a}$ Dropout is equal to 1 if child dropped out of school during the year; otherwise 0 .

${ }^{\mathrm{b}}$ Marks range from 1 (worst) to 5 (best). They are categorical.

${ }^{\mathrm{c}}$ Controls included are school size, school size squared, number of Roma in school, number of Roma in school squared, percentage of Roma per class, class size, class size squared, female $(=1)$, age, age squared, and migrant $(=1)$.

schools applying in the second year. ${ }^{30}$ Fourth, we are in possession of data for three years prior to the introduction of the program and the placebo tests for these years support our claim of no systematic differences between the two groups of schools. Fifth, we do know that the committee for school selection - composed of the Minister of Education and other representatives of the Ministry, representatives of National Council, OSCE, and of the Ministry for Human and Minority Rights - rated schools based on their shown interest and motivation (application) in the same way, in both years. ${ }^{31}$

A second possible estimation strategy is to exploit the fact that older cohorts were less exposed to the program (control group) to younger cohorts (treated group) in Early Enrollee-treated schools. ${ }^{32}$

The main advantage of using as a control group schools which enrolled later in the program is that its impact would not be confounded with other government policies that took place in the year of its introduction. For instance, in 200910 all first-grade pupils got free text books and in the last few years the Ministry strongly suggests to schools to reduce repetition rates especially in the lower grades. The weakness of this control group lies in the fact that we cannot be completely certain that unobservable characteristics are the same in Early Enrollee and Late Enrollee schools. In order to purge time-invariant school characteristics, we can use older cohorts in the treatment schools as a control group. Nonetheless, this econometric strategy relies on the strong assumptions that there were no government interventions over the periodwhich is not exactly our case-and that the outcomes have a regular trend over the years. By combining the Early-Late Enrollee analysis with the cohort specification we better take into account strengths and weaknesses of both approaches.

\section{(a) First approach: comparison of Early Enrollees vs. Late} Enrollees

Our first econometric strategy exploits the fact that some schools received the assistants prior to other schools. We compare Early Enrollee schools with Late Enrollee schools in the years 2008-09-year before the introduction of the program - and 2009-10 - year of the introduction of the program.

\section{(i) Average treatment approach}

Our specification (1) is a difference-in-difference model with school fixed effects:

$Y_{i j t}=\beta_{0}+\delta_{t}+\rho_{j}+\beta_{1}$ treatment $_{j} *$ post $_{t}+\beta_{2} X_{i j t}^{\prime}+\varepsilon_{i j t}$

The outcome variables $Y_{i j t}$ are dropout, hours of absences in a year, and final marks in Serbian and mathematics of child $i$, in 
Table 4. Average treatment approach-Placebo

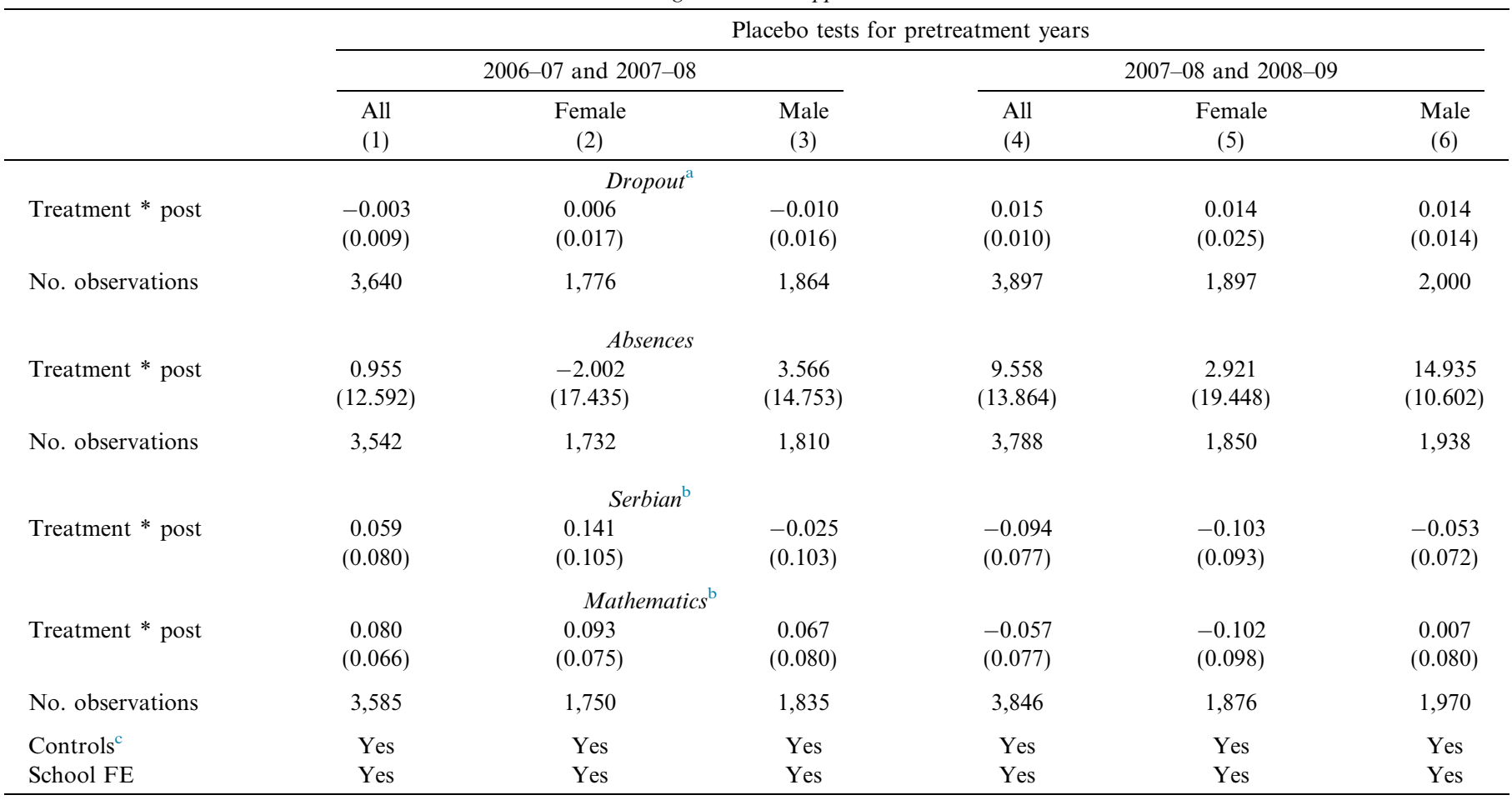

This table reports the results of the placebo regressions for pretreatment years for the average treatment approach. The outcomes of the regressions are dropouts, absences, Serbian and mathematics. Robust standard errors corrected for clustering at the school level are reported in parentheses: * significant at $10 \%,{ }^{* *}$ significant at $5 \%,{ }^{* * *}$ significant at $1 \%$.

${ }^{a}$ Dropout is equal to 1 if child dropped out of school during the year; otherwise 0 .

${ }^{\mathrm{b}}$ Marks range from 1 (worst) to 5 (best). They are categorical.

${ }^{c}$ Controls included are school size, school size squared, number of Roma in school, number of Roma in school squared, percentage of Roma per class, class size, class size squared, female $(=1)$, age, age squared, and migrant $(=1)$.

school $j$ at time $t . \delta_{t}$ is a time fixed effect, $\rho_{j}$ corresponds to school fixed effects, and treatment $_{j} *$ post $_{t}$ is the interaction term between the dummies for treatment status of the school and treatment year. Dropout is a dummy variable taking the value one if child $i$ dropped out of school during year $t$, otherwise it is equal to zero. With school fixed effects we are able to control for time-invariant unobservable school characteristics as well as unobservable geographical characteristics. The control variables $X_{i j t}^{\prime}$ are school size, school size squared, number of Roma in school, number of Roma in school squared, percentage of Roma per class, class size, class size squared, the gender of the child ( $=1$ if the child is female), age, age squared, and whether the child is a migrant $(=1$ if the child was born in the same town where she attends school). The coefficient of interest $\left(\beta_{1}\right)$ is the difference-in-difference estimator of the interaction term between treatment and time that captures the difference in outcomes between the treatment and control schools.

Results for the different outcomes of interest are reported in Table 3. For all outcomes we estimate the regressions without and with controls (columns (1) and (2)). We then split our sample by gender (columns (3) and (4)) to assess whether the impact of the intervention differs by gender. ${ }^{33}$

Overall, results show that the program had a statistically significant impact only on hours of absences: pupils exposed to the program were on average almost $17 \mathrm{~h}$ less absent from school in a year $\left(0.121\right.$ standard deviations). ${ }^{34}$ This is especially the case for male, whose reduction in absences is of roughly $26 \mathrm{~h}$ ( 5 days) or equivalently 0.176 standard deviations. Dropouts and marks in both subjects are unaffected by the program. At first it could seem surprising that dropouts do not respond to the program, but our preliminary data analysis has shown that dropouts are not problematic in the lower four grades. The fact that the inclusion of control variables does not change the magnitude of our coefficients suggests that our coefficients are very robustly estimated.

There are only three settlements where children from both control and treatment schools live together and it is possible that in these settlements children in Early Enrollee and children in Late Enrollee schools interact. If one were to believe that there were spillover effects from treated children on children from control schools, this would imply that coefficients in our regressions are underestimated.

Placebo regressions. The difference-in-difference approach relies on the parallel trends assumption. We assume that, in the absence of the program, treatment and comparison schools would have had a parallel trend in the average outcomes of interest. An obvious way to examine the robustness of our results is to estimate the same regressions (specification (1)) for the years 2006-07 versus 2007-08 and for the years $2007-08$ versus $2008-09$. By estimating the same regressions for pretreatment years, we can test if the outcomes in the two groups of schools were regular before the introduction of the program. Significant difference-in-difference coefficients in placebo regressions would invalidate our estimation strategy and would question the adequacy of our comparison group.

Placebo tests are summarized in Table 4 and we do not find statistically significant coefficients. 
Table 5. Intensity of treatment

\begin{tabular}{|c|c|c|c|c|}
\hline & \multicolumn{4}{|c|}{ Effect of program in treatment year } \\
\hline & $\begin{array}{l}\text { All } \\
\text { (1) }\end{array}$ & $\begin{array}{l}\text { All } \\
(2)\end{array}$ & $\begin{array}{l}\text { Female } \\
\text { (3) }\end{array}$ & $\begin{array}{l}\text { Male } \\
\text { (4) }\end{array}$ \\
\hline \multicolumn{5}{|c|}{ Dropout $^{\text {a }}$} \\
\hline treatment $*$ post & $\begin{array}{l}-0.007 \\
(0.008)\end{array}$ & $\begin{array}{l}-0.001 \\
(0.008)\end{array}$ & $\begin{array}{l}0.009 \\
(0.014)\end{array}$ & $\begin{array}{l}-0.008 \\
(0.012)\end{array}$ \\
\hline Intensive $*$ treatment $*$ post & $\begin{array}{l}0.008 \\
(0.025)\end{array}$ & $\begin{array}{l}0.001 \\
(0.023)\end{array}$ & $\begin{array}{l}0.044 \\
(0.044)\end{array}$ & $\begin{array}{l}-0.038 \\
(0.035)\end{array}$ \\
\hline No. observations & 4,167 & 4,039 & 1,951 & 2,088 \\
\hline \multicolumn{5}{|c|}{ Absences } \\
\hline Treatment $*$ post & $\begin{array}{l}-8.707 \\
(7.720)\end{array}$ & $\begin{array}{l}-4.089 \\
(8.394)\end{array}$ & $\begin{array}{l}1.886 \\
(8.324)\end{array}$ & $\begin{array}{l}-9.058 \\
(11.931)\end{array}$ \\
\hline Intensive $*$ treatment $*$ post & $\begin{array}{l}-19.312 \\
(27.119)\end{array}$ & $\begin{array}{c}-36.390 \\
(24.179)\end{array}$ & $\begin{array}{l}-9.522 \\
(36.096)\end{array}$ & $\begin{array}{l}-59.759^{* *} \\
(24.684)\end{array}$ \\
\hline No. observations & 3,980 & 3,868 & 1,871 & 1,997 \\
\hline \multicolumn{5}{|c|}{ Serbian $^{\mathrm{b}}$} \\
\hline Treatment $*$ post & $\begin{array}{l}-0.027 \\
(0.078)\end{array}$ & $\begin{array}{l}-0.058 \\
(0.080)\end{array}$ & $\begin{array}{l}-0.154^{*} \\
(0.084)\end{array}$ & $\begin{array}{l}0.041 \\
(0.094)\end{array}$ \\
\hline Intensive $*$ treatment $*$ post & $\begin{array}{l}0.330^{*} \\
(0.169)\end{array}$ & $\begin{array}{l}0.307^{* * *} \\
(0.150)\end{array}$ & $\begin{array}{l}0.499^{* *} \\
(0.186)\end{array}$ & $\begin{array}{l}0.108 \\
(0.151)\end{array}$ \\
\hline \multicolumn{5}{|c|}{ Mathematics ${ }^{\mathrm{b}}$} \\
\hline Treatment $*$ post & $\begin{array}{l}-0.053 \\
(0.081)\end{array}$ & $\begin{array}{l}-0.078 \\
(0.080)\end{array}$ & $\begin{array}{l}-0.169 \\
(0.093)\end{array}$ & $\begin{array}{l}0.012 \\
(0.088)\end{array}$ \\
\hline Intensive $*$ treatment $*$ post & $\begin{array}{l}0.454^{* *} \\
(0.152)\end{array}$ & $\begin{array}{l}0.417^{* *} \\
(0.143)\end{array}$ & $\begin{array}{l}0.680^{* * *} \\
(0.179)\end{array}$ & $\begin{array}{l}0.161 \\
(0.138)\end{array}$ \\
\hline No. observations & 4,085 & 3,961 & 1,916 & 2,045 \\
\hline Controls $^{\mathrm{c}}$ & No & Yes & Yes & Yes \\
\hline School FE & No & Yes & Yes & Yes \\
\hline
\end{tabular}

This table reports the effect of the program on dropouts, absences and Serbian and mathematics. Robust standard errors corrected for clustering at the school level are reported in parentheses: ${ }^{*}$ significant at $10 \%,{ }^{* *}$ significant at $5 \%,{ }^{* * *}$ significant at $1 \%$.

${ }^{a}$ Dropout is equal to 1 if child dropped out of school during the year; otherwise 0 .

${ }^{\mathrm{b}}$ Marks range from 1 (worst) to 5 (best). They are categorical.

${ }^{\mathrm{c}}$ Controls included are school size, school size squared, percentage of Roma per class, class size, class size squared, female $(=1)$, age, age squared, migrant $(=1)$, and intensive $(=1)$. Intensive is equal to 1 for schools with fewer than 43 Roma.

The difference-in-difference estimates for Serbian and mathematics are insignificant and negative for the period immediately preceding the introduction of the program (2007-08 versus 2008-09). Even if one were to believe that there was a trend prior to the program, then our estimates for all outcomes are underestimating the effect of the program in the average treatment approach. ${ }^{35}$ The placebo regressions support our claim that Late Enrollees are a good counterfactual for Early Enrollees.

\section{(ii) Intensity of treatment approach}

The design of the intervention permits us to investigate whether the effect of the program varies with the number of Roma per school. Each school has only one assistant: the higher the number of Roma per school, the less intense is the program. If the assistant has to help a high number of students, she will help less each of them: she will be less present both in regular classes and in activities regarding their homework and assignments.

Our intensity specification is a variation of the previous approach; it still uses within-school variation of Roma, but now we exploit also the variation in the number of Roma between schools. We divide schools in two equally sized groups with 19 schools. ${ }^{36}$ The dummy intensive is equal to one for schools with fewer than 43 Roma. ${ }^{37}$ The main difference to the prior model is that we interact the dummy intensive with treatment and time. We believe that differentiating the schools in groups helps to better understand the role of the number of Roma on the impact of the program. The coefficient of interest is now $\beta_{6}$.

The intensity of treatment is modeled:

$$
\begin{aligned}
Y_{i j t}= & \beta_{0}+\delta_{t}+\beta_{1} \text { treatment }_{j}+\beta_{2} \text { treatment }_{j} * \text { post }_{t} \\
& +\beta_{3} \text { intensive_Roma }_{j t}+\beta_{4} \text { intensive_Roma }_{j t} * \text { post }_{t} \\
& +\beta_{5} \text { intensive_Roma }_{j t} * \text { treatment }_{j}+\beta_{6} \text { intensive_Roma }_{j t} \\
& * \text { treatment }_{j} * \text { post }_{t}+\varepsilon_{i j t}
\end{aligned}
$$

Results with and without controls, and for both genders are reported in Table 5 .

The intensity of the program clearly plays a role in explaining its effects. The lower is the number of Roma in a school, and similarly the more the assistant can help them, the higher is the impact on the outcomes of interest. Absences, for instance, reduce on average by roughly $36 \mathrm{~h}$ or equivalently 0.228 standard deviations in a year in schools with less Roma, compared to Late Enrollee schools. The fall in absences is driven by a reduction in absences of boys, almost $60 \mathrm{~h}$ less. The 
Table 6. Intensity of treatment-Placebo

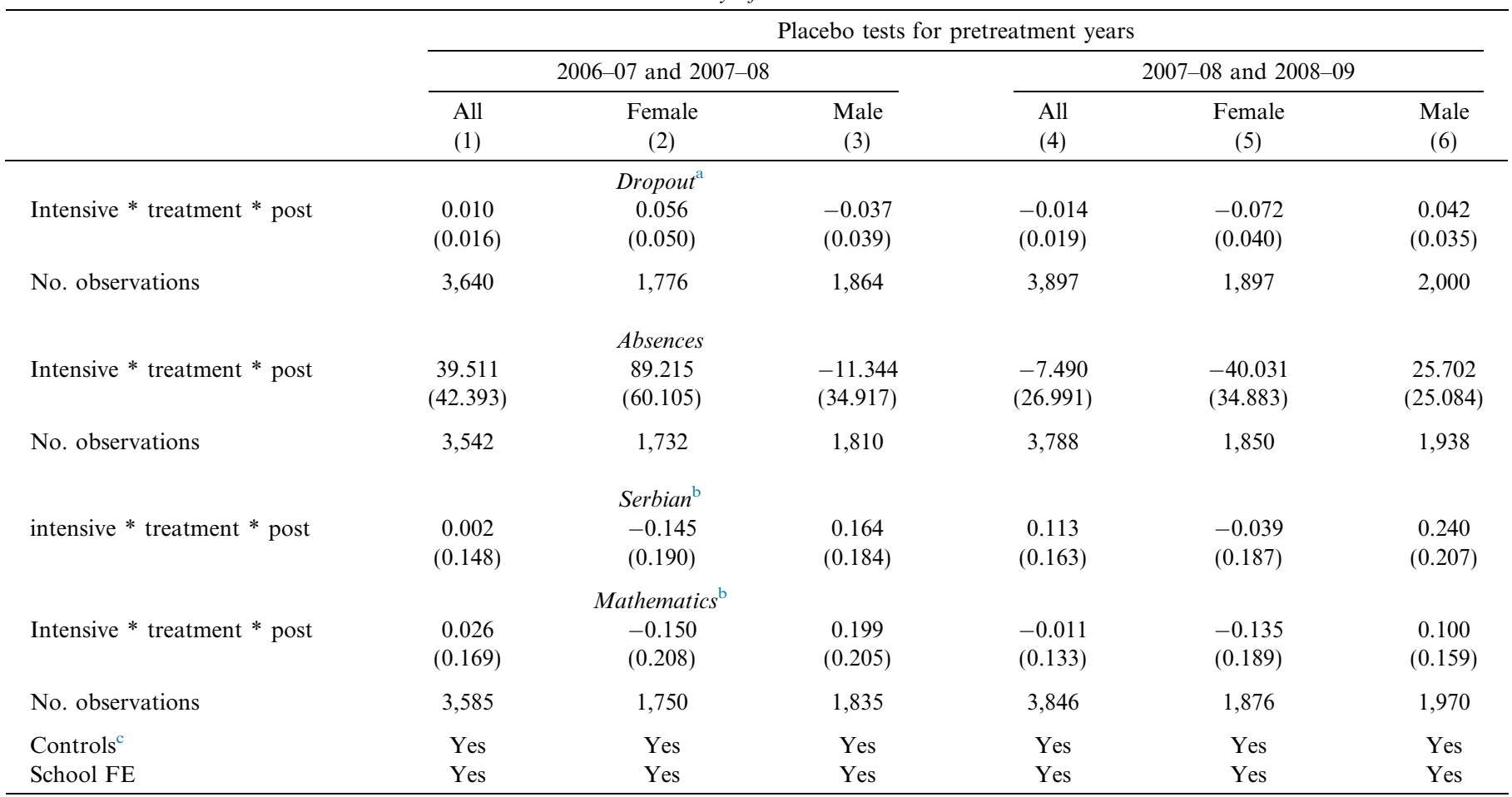

This table reports the results of the placebo regressions for pretreatment years for the intensity of treatment approach. The outcomes of the regressions are dropouts, absences, Serbian and mathematics. Robust standard errors corrected for clustering at the school level are reported in parentheses: * significant at $10 \%,{ }^{* *}$ significant at $5 \%,{ }^{* * *}$ significant at $1 \%$.

${ }^{\text {a }}$ Dropout is equal to 1 if child dropped out of school during the year; otherwise 0 .

${ }^{\mathrm{b}}$ Marks range from 1 (worst) to 5 (best). They are categorical.

${ }^{c}$ Controls included are school size, school size squared, number of Roma in school, number of Roma in school squared, percentage of Roma per class, class size, class size squared, female $(=1)$, age, age squared, migrant $(=1)$, and intensive $(=1)$. Intensive is equal to 1 for schools with fewer than 43 Roma.

effects disappear in schools with a higher number of Roma. Marks in both Serbian and mathematics increase for pupils in Early Enrollee schools with a lower number of Roma, but again these effects do not result in schools with a higher number of Roma. The impacts are especially large for girls, for whom being in a school with a lower number of Roma seems to be more favorable: on average, if exposed to the program in a school with less Roma, their marks in Serbian and mathematics increase by 0.499 (0.419 standard deviations) and 0.680 (0.581 standard deviations). The improvement in test scores is larger in mathematics than in languages and this different response to interventions by subject has been found also in other studies (Fryer, 2014). Possible explanations for the disparity in treatment effects by subject area are offered in Fryer (2014). One theory suggests that language skill development occurs at an earlier age than the development of higher cognitive skills. Another prominent theory suggests that language acquisition and reading test scores are influenced by factors outside the classroom. This is plausible because language skills are used more outside of the classroom than mathematics skills. ${ }^{38}$

Placebo regressions. We estimate placebo regressions of estimation (2) for the years 2006-07 versus 2007-08 and for the years $2007-08$ versus $2008-09$. Placebo tests are summarized in Table 6 .

The coefficients for school grades are positive, but not significant for the period preceding the program (2007-08 versus 2008-09). The coefficients we obtain for the treatment year are much larger than coefficients from our placebo regressions.
For instance, in mathematics (Serbian) we obtain an increase of $0.417(0.307)$ in marks in treatment year, and this number is only $-0.011(0.113)$ for the pretreatment placebo regression. Similarly, for absences the coefficient is negative, but with $-7.490 \mathrm{~h}$ much smaller than the coefficient -36.390 from the main regression. Again, the placebo regressions confirm that Late Enrollees are a good counterfactual for Early Enrollees.

\section{(b) Second approach: cohort regressions and triple difference}

We know that assistants worked mostly with the first-grade ${ }^{39}$ and in the second approach we compare kids in the first grade (young cohorts) with kids in older grades - second, third, and fourth-(old cohorts) in the pre- and treatment year in Early Enrollee-treated schools. Here we assume that the difference in marks between first graders' and second, third, and fourth graders' would have been constant over time, in the absence of the program. We also implicitly assume the absence of policies targeting specific grades. With this econometrics strategy, we are able to purge time-invariant school characteristics. The specification in this section informs us whether the program was successful for the children enrolled in the first grade. We first estimate the following regression for Early Enrollees:

$Y_{i j t}=\beta_{0}+\beta_{1}$ young $_{i}+\beta_{2}$ post $_{t}+\beta_{3}$ young $_{i} *$ post $_{t}+\varepsilon_{i j t}$

where $Y_{i j t}$ are again dropout, hours of absences, and final marks in Serbian and mathematics of child $i$, in school $j$ and at time $t$; young $_{t}$ is equal to 1 when the child is at the first 
Table 7. Cohort regression

\begin{tabular}{|c|c|c|c|c|c|c|c|c|c|}
\hline & \multicolumn{9}{|c|}{ Effect of program in treatment year } \\
\hline & \multicolumn{3}{|c|}{ All } & \multicolumn{3}{|c|}{ Female } & \multicolumn{3}{|c|}{ Male } \\
\hline & $\begin{array}{l}\text { Early enrollees } \\
\text { (1) }\end{array}$ & $\begin{array}{l}\text { Late enrollees } \\
\text { (2) }\end{array}$ & $\begin{array}{l}\text { All } \\
(3)\end{array}$ & $\begin{array}{l}\text { Early enrollees } \\
\text { (4) }\end{array}$ & $\begin{array}{l}\text { Late enrollees } \\
\text { (5) }\end{array}$ & $\begin{array}{l}\text { All } \\
(6)\end{array}$ & $\begin{array}{l}\text { Early enrollees } \\
\text { (7) }\end{array}$ & $\begin{array}{l}\text { Late enrollees } \\
\text { (8) }\end{array}$ & $\begin{array}{l}\text { All } \\
(9)\end{array}$ \\
\hline $\begin{array}{l}\text { Young * post } \\
\text { Young * post * treatment }\end{array}$ & $\begin{array}{c}0.014 \\
(0.013)\end{array}$ & $\begin{array}{l}0.079^{* * *} \\
(0.019)\end{array}$ & $\begin{array}{c}0.080^{* * *} \\
(0.018) \\
-0.066^{* * *} \\
(0.022)\end{array}$ & $\begin{array}{l}\text { Dropout }^{\mathrm{a}} \\
0.031 \\
(0.020)\end{array}$ & $\begin{array}{l}0.071^{* * *} \\
(0.019)\end{array}$ & $\begin{array}{c}0.077^{* * *} \\
(0.018) \\
-0.047^{*} \\
(0.027)\end{array}$ & $\begin{array}{l}-0.003 \\
(0.012)\end{array}$ & $\begin{array}{c}0.087^{* * *} \\
(0.028)\end{array}$ & $\begin{array}{c}0.083^{* * *} \\
(0.028) \\
-0.087^{* * *} \\
(0.029)\end{array}$ \\
\hline No. observations & 2,438 & 1,601 & 4,039 & 1,200 & 751 & 1,951 & 1,238 & 850 & 2,088 \\
\hline $\begin{array}{l}\text { Young * post } \\
\text { Young * post } * \text { treatment }\end{array}$ & $\begin{array}{l}23.579^{*} \\
(11.537)\end{array}$ & $\begin{array}{l}57.493^{* *} \\
(21.263)\end{array}$ & $\begin{array}{l}54.639^{* *} \\
(22.235) \\
-31.867 \\
(24.945)\end{array}$ & $\begin{array}{l}\text { Absences } \\
40.707^{* *} \\
(16.000)\end{array}$ & $\begin{array}{l}67.618^{* *} \\
(28.938)\end{array}$ & $\begin{array}{l}67.603^{* *} \\
(26.469) \\
-28.524 \\
(30.772)\end{array}$ & $\begin{array}{c}9.740 \\
(14.055)\end{array}$ & $\begin{array}{l}52.423^{* *} \\
(22.036)\end{array}$ & $\begin{array}{l}49.480^{* *} \\
(24.287) \\
-40.337 \\
(27.852)\end{array}$ \\
\hline No. observations & 2,336 & 1,532 & 3,868 & 1,152 & 719 & 1,871 & 1,184 & 813 & 1,997 \\
\hline $\begin{array}{l}\text { Young * post } \\
\text { Young * post } * \text { treatment }\end{array}$ & $\begin{array}{c}0.079 \\
(0.102)\end{array}$ & $\begin{array}{c}-0.255^{* *} \\
(0.104)\end{array}$ & $\begin{array}{l}-0.300^{* * *} \\
(0.101) \\
0.382^{* *} \\
(0.149)\end{array}$ & $\begin{array}{l}\text { Serbian }^{\mathrm{b}} \\
0.052 \\
(0.113)\end{array}$ & $\begin{array}{l}-0.284 \\
(0.173)\end{array}$ & $\begin{array}{c}-0.352^{* *} \\
(0.170) \\
0.416^{*} \\
(0.215)\end{array}$ & $\begin{array}{c}0.101 \\
(0.161)\end{array}$ & $\begin{array}{c}-0.295^{*} \\
(0.154)\end{array}$ & $\begin{array}{c}-0.328^{* *} \\
(0.139) \\
0.423^{*} \\
(0.212)\end{array}$ \\
\hline $\begin{array}{l}\text { Young * post } \\
\text { Young } * \text { post } * \text { treatment }\end{array}$ & $\begin{array}{c}0.082 \\
(0.116)\end{array}$ & $\begin{array}{l}-0.241 \\
(0.143)\end{array}$ & $\begin{array}{c}-0.291^{*} \\
(0.152) \\
0.381^{*} \\
(0.194)\end{array}$ & $\begin{array}{l}\text { Mathematics }^{\mathrm{b}} \\
\quad-0.019 \\
(0.132)\end{array}$ & $\begin{array}{l}-0.344 \\
(0.234)\end{array}$ & $\begin{array}{c}-0.426^{*} \\
(0.241) \\
0.428 \\
(0.279)\end{array}$ & $\begin{array}{c}0.180 \\
(0.155)\end{array}$ & $\begin{array}{l}-0.205 \\
(0.142)\end{array}$ & $\begin{array}{c}-0.239^{*} \\
(0.135) \\
0.412^{*} \\
(0.207)\end{array}$ \\
\hline No. observations & 2,395 & 1,567 & 3,962 & 1,180 & 736 & 1,916 & 1,215 & 831 & 2,046 \\
\hline $\begin{array}{l}\text { Controls }^{\mathrm{c}} \\
\text { School FE }\end{array}$ & $\begin{array}{l}\text { Yes } \\
\text { Yes }\end{array}$ & $\begin{array}{l}\text { Yes } \\
\text { Yes }\end{array}$ & $\begin{array}{l}\text { Yes } \\
\text { Yes }\end{array}$ & $\begin{array}{l}\text { Yes } \\
\text { Yes }\end{array}$ & $\begin{array}{l}\text { Yes } \\
\text { Yes }\end{array}$ & $\begin{array}{l}\text { Yes } \\
\text { Yes }\end{array}$ & $\begin{array}{l}\text { Yes } \\
\text { Yes }\end{array}$ & $\begin{array}{l}\text { Yes } \\
\text { Yes }\end{array}$ & $\begin{array}{l}\text { Yes } \\
\text { Yes }\end{array}$ \\
\hline
\end{tabular}

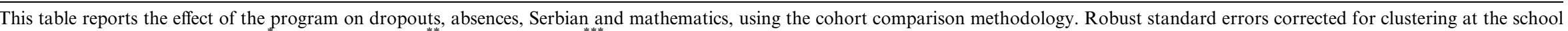
level are reported in parentheses: "significant at $10 \%,{ }^{* *}$ significant at $5 \%,{ }^{* * *}$ significant at $1 \%$.

${ }^{a}$ Dropout is equal to 1 if child dropped out of school during the year; otherwise 0 .

${ }^{\mathrm{b}}$ Marks range from 1 (worst) to 5 (best). They are categorical.

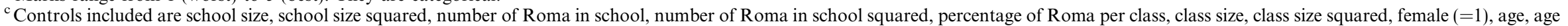
squared, migrant $(=1)$ and young $(=1)$. Young is equal to 1 when the child is at the first grade. 
Table 8. Cohort regression-Placebo

\begin{tabular}{|c|c|c|c|c|c|c|}
\hline & \multicolumn{6}{|c|}{ Placebo tests for pretreatment years } \\
\hline & \multicolumn{3}{|c|}{ 2006-07 and 2007-08 } & \multicolumn{3}{|c|}{ 2007-08 and 2008-09 } \\
\hline & $\begin{array}{c}\text { Early enrollees } \\
\text { (1) }\end{array}$ & $\begin{array}{l}\text { Late enrollees } \\
\text { (2) }\end{array}$ & $\begin{array}{l}\text { All } \\
(3)\end{array}$ & $\begin{array}{c}\text { Early enrollees } \\
\text { (4) }\end{array}$ & $\begin{array}{l}\text { Late enrollees } \\
\qquad(5)\end{array}$ & $\begin{array}{l}\text { All } \\
(6)\end{array}$ \\
\hline \multicolumn{7}{|c|}{ Dropout $^{\text {a }}$} \\
\hline Young * post & $\begin{array}{c}0.003 \\
(0.017)\end{array}$ & $\begin{array}{c}0.008 \\
(0.017)\end{array}$ & $\begin{array}{c}0.011 \\
(0.015)\end{array}$ & $\begin{array}{l}-0.020 \\
(0.015)\end{array}$ & $\begin{array}{l}-0.036^{* *} \\
(0.012)\end{array}$ & $\begin{array}{c}-0.037^{* * *} \\
(0.013)\end{array}$ \\
\hline Young $*$ post $*$ treatment & & & $\begin{array}{l}-0.010 \\
(0.024)\end{array}$ & & & $\begin{array}{c}0.019 \\
(0.020)\end{array}$ \\
\hline No. observations & 2,259 & 1,381 & 3,640 & 2,389 & 1,508 & 3,897 \\
\hline \multicolumn{7}{|c|}{ Absences } \\
\hline Young * post & $\begin{array}{l}-14.021 \\
(17.068)\end{array}$ & $\begin{array}{l}-56.385^{*} \\
(27.822)\end{array}$ & $\begin{array}{l}-54.237^{*} \\
(28.643)\end{array}$ & $\begin{array}{c}-9.425 \\
(13.600)\end{array}$ & $\begin{array}{l}-13.207 \\
(16.765)\end{array}$ & $\begin{array}{l}-13.596 \\
(18.055)\end{array}$ \\
\hline Young $*$ post $*$ treatment & & & $\begin{array}{c}34.591 \\
(32.454)\end{array}$ & & & $\begin{array}{c}10.100 \\
(23.240)\end{array}$ \\
\hline No. observations & 2,203 & 1,339 & 3,542 & 2,331 & 1,457 & 3,788 \\
\hline \multicolumn{7}{|c|}{ Serbian $^{\mathrm{b}}$} \\
\hline Young $*$ post & $\begin{array}{c}0.030 \\
(0.207)\end{array}$ & $\begin{array}{c}0.143 \\
(0.194)\end{array}$ & $\begin{array}{c}0.105 \\
(0.203)\end{array}$ & $\begin{array}{l}-0.167 \\
(0.178)\end{array}$ & $\begin{array}{c}0.034 \\
(0.154)\end{array}$ & $\begin{array}{c}0.043 \\
(0.156)\end{array}$ \\
\hline Young $*$ post $*$ treatment & & Mat & $\begin{array}{l}-0.024 \\
(0.278) \\
i c s^{\mathrm{b}}\end{array}$ & & & $\begin{array}{l}-0.244 \\
(0.231)\end{array}$ \\
\hline Young * post & $\begin{array}{c}0.164 \\
(0.237)\end{array}$ & $\begin{array}{c}0.117 \\
(0.180)\end{array}$ & $\begin{array}{c}0.086 \\
(0.185)\end{array}$ & $\begin{array}{l}-0.101 \\
(0.145)\end{array}$ & $\begin{array}{l}-0.115 \\
(0.197)\end{array}$ & $\begin{array}{l}-0.113 \\
(0.196)\end{array}$ \\
\hline Young $*$ post $*$ treatment & & & $\begin{array}{c}0.122 \\
(0.286)\end{array}$ & & & $\begin{array}{l}-0.022 \\
(0.239)\end{array}$ \\
\hline No. observations & 2,232 & 1,354 & 3,586 & 2,364 & 1,482 & 3,846 \\
\hline Controls $^{\mathrm{c}}$ & Yes & Yes & Yes & Yes & Yes & Yes \\
\hline School FE & Yes & Yes & Yes & Yes & Yes & Yes \\
\hline
\end{tabular}

This table reports the results of the placebo regressions for pretreatment years for cohort comparison methodology. The outcomes of the regressions are dropouts, absences, Serbian and mathematics. Robust standard errors corrected for clustering at the school level are reported in parentheses: * ${ }^{*}$ ignificant at $10 \%,{ }^{* *}$ significant at $5 \%,{ }^{* * *}$ significant at $1 \%$.

${ }^{a}$ Dropout is equal to 1 if child dropped out of school during the year; otherwise 0 .

${ }^{\mathrm{b}}$ Marks range from 1 (worst) to 5 (best). They are categorical.

${ }^{c}$ Controls included are school size, school size squared, number of Roma in school, number of Roma in school squared, percentage of Roma per class, class size, class size squared, female $(=1)$, age, age squared, migrant $(=1)$ and young $(=1)$. Young is equal to 1 when the child is at the first grade.

grade; post $_{t}$ is equal to 1 in the year of the treatment (2009-10). The coefficient of interest is now $\beta_{3}$ which tells us how the first graders have performed compared to the older grades.

The same regression (3) is then estimated for Late Enrollees and the triple difference between treated and control schools and cohorts is captured by $\gamma_{3}$ in the following specification:

$$
\begin{aligned}
Y_{i j t}= & \beta_{0}+\beta_{1} \text { young }_{i}+\beta_{2} \text { post }_{t}+\beta_{3} \text { young }_{i} * \text { post }_{t} \\
& +\gamma_{1} \text { treatment }_{j} * \text { post }_{t}+\gamma_{2} \text { young }_{i} * \text { treatment }_{j} \\
& +\gamma_{3} \text { young }_{i} * \text { post }_{t} * \text { treatment }_{j}+\varepsilon_{i j t}
\end{aligned}
$$

Unlike estimation (3), regression (4) does not control for possible unobservable differences between schools. By estimating cohort regressions on a pooled sample of Early and Late Enrollees, we can control for government policies targeting specific grades. ${ }^{40}$

The regressions are estimated with controls and we also inspect the impacts by gender. Results are shown in Table 7 .

When comparing first graders with older pupils in only Early Enrollee schools (column (1)), our coefficients of interest have, with the exception of absences, the correct sign, but are not statistically significant. We are not overly concerned that absences increase, because we observe a similar pattern also in Late Enrollee-control schools (see column (2) in Table 7). We believe that the overall increase in dropouts is a consequence of visa liberalization: some families have migrated to EU countries. ${ }^{41}$ Results of the triple interaction for the full sample are reported in column (3) in Table 7. Coefficients for dropouts are statistically significant. Absences decrease for the young cohort, but they do not reach statistical significance. Pupils exposed to the program in the first grade get higher marks than first graders in Late Enrollee-control schools (with respect to their older mates). This effect is partly driven by the worse outcomes of first-grade pupils in Late Enrollee-control schools. On average, being in a Early Enrollee school increases marks in Serbian and mathematics by 0.296 and 0.284 standard deviations for first graders.

Placebo regressions. We test the robustness of our results by estimating placebo regressions (regression (3), (4)) for the years $2006-07$ versus $2007-08$ and for the years $2007-08$ versus 2008-09 (see Table 8).

None of the relevant coefficients is significant. The size of the coefficient for Serbian for 2007-08 versus 2008-09 is insignificant, but not completely negligible. Absences for the 
Table 9. Balancing tables for intensity of treament approach for pre-and treatment year

\begin{tabular}{|c|c|c|c|c|c|c|}
\hline & \multicolumn{3}{|c|}{ Pre-treatment year } & \multicolumn{3}{|c|}{ Treatment year } \\
\hline & $\begin{array}{l}\text { Early enrollees } \\
\text { (1) }\end{array}$ & $\begin{array}{l}\text { Late enrollees } \\
\text { (2) }\end{array}$ & $\begin{array}{c}\text { Difference } \\
(3)(1)-(2)\end{array}$ & $\begin{array}{l}\text { Early enrollees } \\
\text { (4) }\end{array}$ & $\begin{array}{l}\text { Late enrollees } \\
\text { (5) }\end{array}$ & $\begin{array}{c}\text { Difference } \\
(6)(4)-(5)\end{array}$ \\
\hline \multicolumn{7}{|c|}{ Dropout $^{\mathrm{a}}$} \\
\hline Less Roma & 0.015 & 0.026 & $\begin{array}{l}-0.011 \\
(0.016)\end{array}$ & 0.035 & 0.044 & $\begin{array}{c}0.009 \\
(0.026)\end{array}$ \\
\hline More Roma & 0.021 & 0.019 & $\begin{array}{l}-0.002 \\
(0.007)\end{array}$ & 0.023 & 0.033 & $\begin{array}{l}-0.010 \\
(0.010)\end{array}$ \\
\hline \multicolumn{7}{|c|}{ Absences (h) } \\
\hline Less Roma & 143.691 & 146.399 & $\begin{array}{c}-2.708 \\
(33.530)\end{array}$ & 141.220 & 171.947 & $\begin{array}{l}-30.727 \\
(39.283)\end{array}$ \\
\hline More Roma & 109.800 & 120.637 & $\begin{array}{l}-10.837 \\
(13.648)\end{array}$ & 131.583 & 151.127 & $\begin{array}{l}-19.544 \\
(18.262)\end{array}$ \\
\hline \multicolumn{7}{|c|}{ Serbian $^{\mathrm{b}}$} \\
\hline Less Roma & 2.529 & 2.613 & $\begin{array}{l}-0.084 \\
(0.234)\end{array}$ & 2.680 & 2.461 & $\begin{array}{c}0.219 \\
(0.212)\end{array}$ \\
\hline More Roma & 2.397 & 2.531 & $\begin{array}{c}-0.135 \\
(0.147) \\
\text { Mathematics }^{\mathrm{b}}\end{array}$ & 2.436 & 2.598 & $\begin{array}{l}-0.162 \\
(0.167)\end{array}$ \\
\hline Less Roma & 2.380 & 2.513 & $\begin{array}{l}-0.133 \\
(0.219)\end{array}$ & 2.549 & 2.281 & $\begin{array}{c}0.268 \\
(0.213)\end{array}$ \\
\hline More Roma & 2.252 & 2.337 & $\begin{array}{l}-0.085 \\
(0.151)\end{array}$ & 2.305 & 2.443 & $\begin{array}{l}-0.138 \\
(0.182)\end{array}$ \\
\hline
\end{tabular}

This table reports the results of balancing tests for pretreatment and treatment year for the intensity of treatment approach. Robust standard errors corrected for clustering at the school level are reported in parentheses: ${ }^{*}$ significant at $10 \%,{ }^{* *}$ significant at $5 \%$, ${ }^{* * *}$ significant at $1 \%$.

${ }^{a}$ Dropout is equal to 1 if child dropped out of school during that year; otherwise 0 .

${ }^{\mathrm{b}}$ Marks range from 1 (worst) to 5 (best). They are categorical.

two placebo tests are positive, but we obtain a reduction in absences for the treatment year. Similarly, the sign of the coefficient suggests a worsening of marks for Serbian for younger cohorts, exactly the opposite of what we find for the year of treatment.

\section{CONCLUSION AND DISCUSSION}

In this paper we estimate the impact of the Roma Teaching Assistant Program in its first year of implementation on schooling outcomes. We use a difference-in-difference approach by exploiting the gradual introduction of the program. We argue that the assignment to enter the program earlier/later can be treated "as if random". As an additional check, we use a second econometric strategy. We compare pupils of the first grade from treated schools with older cohorts from the same schools. This econometric strategy controls well for school-specific characteristics, but we are not able to control for government interventions over the observed period. We can combine the two approaches (Early-Late Enrollees with cohort analysis) and estimate the triple difference between young and old cohorts in treated and control schools.

Results of our analysis show that the program had on average a positive effect. There is evidence that absences fell by 0.121 standard deviations in treated schools $(17 \mathrm{~h}$, i.e., three to four days). The remedial education part of the program targeted mainly first graders. Our analysis suggests that, for this group, marks have improved by almost 0.296 standard deviations in Serbian and 0.284 standard deviations in mathematics. For the lower primary school grades, dropouts are low in both Early and Late Enrollees and are not a major problem. Higher impacts are obtained in schools with a lower number of Roma: the higher is their number, the less the assistant can help them, and the lower is the impact of the program on the outcomes of interest. In schools with fewer Roma, girls seem to benefit more from the program in terms of better marks, whereas boys exhibit lower absences. With our data it is not possible to explain this differential impact of the program. We do not know if assistants worked more with girls (boys) or if girls (boys) responded better to the program in the case of marks (absences).

While first graders in treated schools perform better than their older colleagues, overall the program does not seem to have a significant impact on pupils' achievement. This is likely the case because assistants work mainly with lower grades and young cohorts are those really exposed to them. Therefore, the general modest effects should not be interpreted as a failure of the program. Moreover, this study looks only at its impact in the first year. It is possible that assistants and schools need some time to adjust to the new role of the assistant and that the full benefit from them will come at a later stage. This idea is also supported by the literature on the importance of the experience of teachers which emphasizes that gains in teaching skills are largest in the initial years of teaching (Rivkin, Hanushek, \& Kain, 2005). Still, our results suggest that the program is more effective in schools with less Roma. We are aware that it is possible that there are systematic differences between schools with a lower and a higher share of Roma. One could argue, for instance, that Roma in schools with a lower share are more willing to adapt and assimilate to the majority population. We cannot be certain that the same effects could be attained in schools with higher percentage of Roma if more assistants were assigned to these schools. It still seems plausible that if the goal of the policy maker is to close the gap in schooling outcomes, then more Roma teaching assistants should be assigned to schools with more Roma students. 
Table 10. Intensity of treatment: Sensitivity analysis

\begin{tabular}{|c|c|c|c|c|c|c|c|c|c|}
\hline & $\begin{array}{l}\text { 1st decile } \\
\text { (1) }\end{array}$ & $\begin{array}{l}\text { Up to } 2 \text { nd decile } \\
\text { (2) }\end{array}$ & $\begin{array}{l}\text { Up to } 3 \text { rd decile } \\
\text { (3) }\end{array}$ & $\begin{array}{c}\text { Up to } 4 \text { th decile } \\
\text { (4) }\end{array}$ & $\begin{array}{c}\text { Up to } 5 \text { th decile } \\
\text { (5) }\end{array}$ & $\begin{array}{c}\text { Up to } 6 \text { th decile } \\
\text { (6) }\end{array}$ & $\begin{array}{c}\text { Up to } 7 \text { th decile } \\
\text { (7) }\end{array}$ & $\begin{array}{c}\text { Up to } 8 \text { th decile } \\
(8)\end{array}$ & $\begin{array}{l}\text { Up to } 9 \text { th decile } \\
\text { (9) }\end{array}$ \\
\hline Intensive $*$ treatment $*$ post & $\begin{array}{c}0.032 \\
(0.032)\end{array}$ & $\begin{array}{c}0.031 \\
(0.037)\end{array}$ & $\begin{array}{l}-0.011 \\
(0.033)\end{array}$ & \begin{tabular}{l}
\multicolumn{1}{c}{ Dropou } \\
-0.000 \\
$(0.029)$
\end{tabular} & $\begin{array}{c}0.001 \\
(0.023)\end{array}$ & $\begin{array}{c}0.010 \\
(0.018)\end{array}$ & $\begin{array}{c}0.007 \\
(0.017)\end{array}$ & $\begin{array}{l}-0.007 \\
(0.015)\end{array}$ & $\begin{array}{c}0.005 \\
(0.012)\end{array}$ \\
\hline Intensive $*$ treatment $*$ post & $\begin{array}{l}-47.636 \\
(34.443)\end{array}$ & $\begin{array}{l}-47.970 \\
(34.788)\end{array}$ & $\begin{array}{c}-75.063^{* *} \\
(31.415)\end{array}$ & $\begin{array}{l}\quad \text { Absenc } \\
-49.650^{*} \\
(29.079)\end{array}$ & $\begin{array}{l}-36.390 \\
(24.179)\end{array}$ & $\begin{array}{l}-20.643 \\
(17.668)\end{array}$ & $\begin{array}{l}-11.530 \\
(16.936)\end{array}$ & $\begin{array}{l}-12.136 \\
(15.706)\end{array}$ & $\begin{array}{c}7.308 \\
(13.351)\end{array}$ \\
\hline Intensive $*$ treatment $*$ post & $\begin{array}{c}0.204 \\
(0.136)\end{array}$ & $\begin{array}{c}0.500 \\
(0.354)\end{array}$ & $\begin{array}{l}0.457^{* *} \\
(0.190)\end{array}$ & $\begin{array}{l}\quad \text { Serbiar } \\
0.364^{* *} \\
(0.163)\end{array}$ & $\begin{array}{l}0.307^{* *} \\
(0.150)\end{array}$ & $\begin{array}{l}0.217^{*} \\
(0.122)\end{array}$ & $\begin{array}{l}0.265^{* *} \\
(0.105)\end{array}$ & $\begin{array}{c}0.175 \\
(0.105)\end{array}$ & $\begin{array}{c}0.133 \\
(0.091)\end{array}$ \\
\hline Intensive $*$ treatment $*$ post & $\begin{array}{l}0.806^{* * *} \\
(0.126)\end{array}$ & $\begin{array}{l}0.650^{* *} \\
(0.258)\end{array}$ & $\begin{array}{c}0.617^{* * *} \\
(0.214)\end{array}$ & $\begin{array}{l}\text { Mathema } \\
0.422^{* *} \\
(0.178)\end{array}$ & $\begin{array}{l}t_{i c s^{\mathrm{b}}} \\
\qquad \begin{array}{l}0.417^{* * *} \\
(0.143)\end{array}\end{array}$ & $\begin{array}{c}0.391^{* * *} \\
(0.121)\end{array}$ & $\begin{array}{c}0.347^{* * *} \\
(0.117)\end{array}$ & $\begin{array}{l}0.280^{* *} \\
(0.105)\end{array}$ & $\begin{array}{c}0.353^{* * *} \\
(0.080)\end{array}$ \\
\hline No. observations & 3,961 & 3,961 & 3,961 & 3,961 & 3,961 & 3,961 & 3,961 & 3,961 & 3,961 \\
\hline Controls $^{\mathrm{c}}$ & Yes & Yes & Yes & Yes & Yes & Yes & Yes & Yes & Yes \\
\hline School FE & Yes & Yes & Yes & Yes & Yes & Yes & Yes & Yes & Yes \\
\hline
\end{tabular}

This table reports the effect of the program on dropout, absences, Serbian and mathematics for different thresholds. We order the schools based on the number of Roma in a school. In column (1) we define the program as "intensive" in schools of the 1st decile (max. 16 Roma per school), column (2) up to 2nd decile (max. 23 Roma per school), column (3) up to 3rd decile (max. 29 Roma per school),

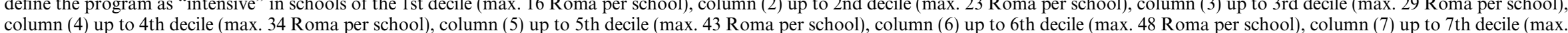

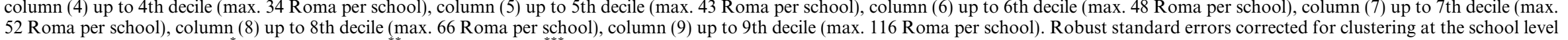
are reported in parentheses: ${ }^{*}$ significant at $10 \%,{ }^{* *}$ significant at $5 \%,{ }^{* * *}$ significant at $1 \%$

${ }^{a}$ Dropout is equal to 1 if child dropped out of school during that year; otherwise 0 .

${ }^{\mathrm{b}}$ Marks range from 1 (worst) to 5 (best). They are categorical.

${ }^{\mathrm{c}}$ Controls included are school size, school size squared, percentage of Roma per class, class size, class size squared, female $(=1)$, age, age squared, migrant (=1), and intensive (=1). Intensive is equal to 1

in column (1) if school falls into first decile, in column (2) if school falls into first or second decile, etc. 
Table 11. Average treatment approach—Non Roma

\begin{tabular}{|c|c|c|c|}
\hline & \multicolumn{3}{|c|}{ Effect of program in treatment year on Non Roma } \\
\hline & $\begin{array}{l}\text { Absences } \\
\text { (1) }\end{array}$ & $\begin{array}{l}\text { Serbian }^{\mathrm{a}} \\
\text { (2) }\end{array}$ & $\begin{array}{c}\text { Mathematics } \\
\text { (3) }\end{array}$ \\
\hline Post & $\begin{array}{l}5.025^{* * *} \\
(1.185)\end{array}$ & $\begin{array}{l}-0.011 \\
(0.031)\end{array}$ & $\begin{array}{c}0.011 \\
(0.018)\end{array}$ \\
\hline Treatment $*$ post & $\begin{array}{l}-1.586 \\
(1.725)\end{array}$ & $\begin{array}{c}0.054 \\
(0.034)\end{array}$ & $\begin{array}{c}0.029 \\
(0.025)\end{array}$ \\
\hline
\end{tabular}

This table reports the effect of the program on Non Roma for absences, Serbian and mathematics. Robust standard errors corrected for clustering at the school level are reported in parentheses: ${ }^{*}$ significant at $10 \%,{ }^{* *}$ significant at $5 \%,{ }^{* * *}$ significant at $1 \%$.

${ }^{\text {a }}$ Marks range from 1 (worst) to 5 (best). They are categorical.

${ }^{\mathrm{b}}$ Controls included are school size, school size squared, number of Roma in school, number of Roma in school squared, percentage of Roma per class, class size, class size squared, female $(=1)$, age, age squared, and migrant $(=1)$.

Table 12. Cohort regression-Non Roma

\begin{tabular}{|c|c|c|c|c|c|c|c|c|c|}
\hline & \multicolumn{9}{|c|}{ Effect of program in treatment year on Non Roma } \\
\hline & \multicolumn{3}{|c|}{ Absences } & \multicolumn{3}{|c|}{ Serbian $^{\mathrm{a}}$} & \multicolumn{3}{|c|}{ Mathematics $^{\mathrm{a}}$} \\
\hline & $\begin{array}{c}\text { Early } \\
\text { enrollees } \\
(1)\end{array}$ & $\begin{array}{c}\text { Late } \\
\text { enrollees } \\
(2)\end{array}$ & $\begin{array}{l}\text { All } \\
\text { (3) }\end{array}$ & $\begin{array}{c}\text { Early } \\
\text { enrollees } \\
(4)\end{array}$ & $\begin{array}{c}\text { Late } \\
\text { enrollees } \\
(5)\end{array}$ & $\begin{array}{l}\text { All } \\
\text { (6) }\end{array}$ & $\begin{array}{c}\text { Early } \\
\text { enrollees } \\
(7)\end{array}$ & $\begin{array}{c}\text { Late } \\
\text { enrollees } \\
(8)\end{array}$ & $\begin{array}{l}\text { All } \\
(9)\end{array}$ \\
\hline Young * post & $\begin{array}{c}0.658 \\
(2.682)\end{array}$ & $\begin{array}{c}3.178 \\
(3.274)\end{array}$ & $\begin{array}{c}3.259 \\
(3.057)\end{array}$ & $\begin{array}{c}0.033 \\
(0.072)\end{array}$ & $\begin{array}{l}-0.056 \\
(0.077)\end{array}$ & $\begin{array}{l}-0.066 \\
(0.069)\end{array}$ & $\begin{array}{c}0.044 \\
(0.058)\end{array}$ & $\begin{array}{l}-0.062 \\
(0.085)\end{array}$ & $\begin{array}{l}-0.070 \\
(0.079)\end{array}$ \\
\hline Young $*$ post $*$ treatment & & & $\begin{array}{c}2.787 \\
(4.986)\end{array}$ & & & $\begin{array}{l}-0.037 \\
(0.107)\end{array}$ & & & $\begin{array}{l}-0.049 \\
(0.111)\end{array}$ \\
\hline No. observations & 8,099 & 6,587 & 14,686 & 8,232 & 6,750 & 14,982 & 8,232 & 6,749 & 14,981 \\
\hline Controls $^{\mathrm{b}}$ & Yes & Yes & Yes & Yes & Yes & Yes & Yes & Yes & Yes \\
\hline School FE & Yes & Yes & Yes & Yes & Yes & Yes & Yes & Yes & Yes \\
\hline
\end{tabular}

This table reports the effect of the program on Non Roma for absences, Serbian and mathematics. Robust standard errors corrected for clustering at the school level are reported in parentheses: ${ }^{*}$ significant at $10 \%,{ }^{* *}$ significant at $5 \%,{ }^{* * *}$ significant at $1 \%$.

${ }^{\text {a }}$ Marks range from 1 (worst) to 5 (best). They are categorical.

${ }^{\mathrm{b}}$ Controls included are school size, school size squared, number of Roma in school, number of Roma in school squared, percentage of Roma per class, class size, class size squared, female $(=1)$, age, age squared, migrant $(=1)$ and young $(=1)$. Young is equal to 1 when the child is at the first grade.

We are not able to delve into the mechanism which drives our results and our estimates are derived from reduced form regressions. Still, our results could and probably are driven by two main mechanisms. First, the RTA intervention alters the inputs of the education production function. Moreover, negative stereotypes about Roma students are softened and teachers could provide more support in learning. The input of teaching is augmented and this can explain better marks of first-grade students. A second mechanism possibly at play is the cultural transmission of preferences for education. The presence of a person coming from the same Roma ethnic background could alter the preferences for education and beliefs of Roma pupils, which induces them to attend more school and to exert more effort at school.

In the context of the literature on schooling of Roma communities, our study makes two important contributions. First, to our knowledge there are no rigorous evaluations of other educational interventions targeting Roma children and our study is the first step in this direction. Ideally, the policy maker would like to know about a range of possible policies and their exact effects and costs. Our study provides clear evidence about the effects of the RTA Program on a range of outcomes. Second, a key part of the RTA Program is the role model component, that is the teaching assistants have the same background as the treated children. The success of this program is likely to be related to this fact because the assistants know well the Roma culture and are accepted by the Roma community. Thus, our study suggests that programs targeting Roma should take into account their culture and specificity and ensure that the program gets accepted by the community.

This paper has laid the foundations for understanding better the RTA Program, but some limitations of the study exist and need to be pointed out. The nation we study is a post-communist nation and we believe that our findings are suggestive and applicable also to other Eastern European countries which share a similar political history with Serbia, but not necessarily to all other countries. During communism the Eastern European countries have implemented inclusive policies toward Roma and in this period the situation of Roma improved despite the fact that they remained at the bottom of all socio-economic indicators (Barany, 2000). In these countries Roma are predominantly sedentary and their assimilation process, especially with respect to education, has started a while ago.

In this paper we look only at the short-term effects. The impacts we observe are suggestive of positive potential 
implications for households and schools. Kids are going more to school and this, in the long-run, can lead to persistent effects in the labor market and improvement in Roma well-being and social inclusion. Moreover, negative stereotypes about Roma students can be softened and this in turn can affect positively both the school environment and school quality. The mediumand long-run effects would be more informative on the real success of the program. Future research in this direction is highly advised in order to understand fully the effectiveness of the program.

\section{NOTES}

1. The number of Roma and the subsequent numbers refer to the following countries: Albania, Bosnia, and Herzegovina, Bulgaria, Croatia, Czech Republic, Estonia, Hungary, Kosovo, Latvia, Lithuania, Republic of Macedonia, Moldova, Montenegro, Poland, Romania, Serbia, Slovakia, Slovenia, and Ukraine.

2. In 2011 , the share of Roma aged 10-18 who have never attended school varies among countries and it can reach percentages above 20. Primary school attendance rates are in the range of $60 \%$ to $80 \%$ in most countries, with some countries going from $40 \%$ to $50 \%$ (Brueggemann, 2012).

3. The Serbian name of the program is Romski Asistenti-Pomoc $u$ Nastavi.

4. Almost all the empirical literature on affirmative actions focuses on the United States experience. There are some studies in developing countries, especially in India, where the debate on affirmative action to address the issues of inclusion and equity has been in place for a long time (Basant \& Sen, 2014). In Europe less extensive investigation has been carried on in this respect.

5. Strictly speaking this study bases its conclusions on correlations and not on causal inference.

6. Kertesi and Kezdi (2011) report a gap of one standard deviation for reading and mathematics in the eight grade between Roma and Non Roma in Hungary. The gap disappears in reading and decreases by $85 \%$ in mathematics when accounting for health, family background, and school and class fixed effects. In Serbia, using national assessments, Baucal (2006) reports that in the third grade of primary school Roma children are already lacking behind their Non Roma peers. The achievement gap decreases by $40 \%$ when the lower socio-economical status of Roma is taken into account.

7. Recent literature emphasizes the importance of affecting the demand for education. A prominent type of demand side programs are conditional cash transfers which raised enrollment and attendance in many developing countries (Schultz, 2004). The provision of financial incentives is an alternative intervention operating on the demand side (Fryer, 2011).

8. Special schools are schools for children with special educational needs.

9. With few exceptions, the rest declare Romani to be their mother tongue.

10. 64 out of 78 schools that applied had a percentage of Roma between $5 \%$ and $40 \%$. Among these 64 , OSCE selected 19 schools (out of 26) with a preschool program, five schools (out of 36) with no preschool program and two schools (out of two) for which no information is available.

11. The following criteria were taken into account for the ranking of the assistants' applications: highest level of education completed or enrolled (from 10 to 30 points), experience in working with Roma children (0-10 points), experience in working on projects related to education $(0-10$ points), motivation ( $0-10$ points), attendance of relevant seminars and/or courses ( $0-10$ points), experience as Roma teaching assistant (0-10 points), knowledge of Romani ( $0-10$ points) and additional points (0-10 points).

12. Unfortunately we do not have information on the availability of a preschool program for schools applying in 2010-11. Nonetheless, it is worthy to recall that some schools without the compulsory preschool program have also been selected in the previous year.

13. Roma pupils joining Early Enrollee schools in the pretreatment yea r-2008-09-corresponded to $29 \%$ of all Roma enrolled in these schools. In Late Enrollees they were 26\%. In the first year of the program-200910 - these percentages were $29 \%$ and $28 \%$. The number of Roma pupils enrolling at school for the first time remained the same in Early Enrollee schools and increased slightly in Late Enrollee schools. The difference between the two types of schools is neglibible.

14. There was a suggested time allocation. The 30 weekly hours of the assistant could be distributed in the following way: work at school (19 h), work with the local community, $(8 \mathrm{~h})$ and writing reports and documentation $(3 \mathrm{~h})$

15. In most cases Roma live in segregated settlements so that assistants can go to the settlement and visit several families at once.

16. In total, the assistants attended 22 working days of seminars and courses in the scholastic year 2009-10. Regular seminars provided the opportunity to the Ministry to understand the problems of the assistants and guide them through the initial difficulties. In 2010-11 a set of nine modules, which all assistants had to attend in their first year of service, was devised.

17. In total, there were 26 schools which got an assistant in 2009-10. In 3 schools we were not allowed to collect data. These schools do not differ from the other schools either in the number of pupils or in the percentage of Roma children and they are located in different areas: one in Belgrade, one in Central Serbia, and one in the South

18. A district is made up of more municipalities. In Serbia there are 24 districts and 160 municipalities.

19. In a few cases the school chosen was not available and we needed to select the second option.

20. 10 schools are located in Belgrade; eight schools in the central area of the nation (five schools in the municipality of Valjevo and three in the municipality of Novi Sad); 12 schools in South-Eastern Serbia (three schools in the municipality of Jagodina, two in Kragujevac, three in Kruševac, three in Zaječar, and one in Požarevac); eight schools in the South of the nation (six schools in the municipality of Leskovac and two in the municipality of Niš). We define urban area as a municipality with more than 35,000 inhabitants.

21. More detailed information regarding the primary education system in Serbia is provided in Section A.1 in the Appendix. 
22. Roma in Serbia are mainly sedentary: they do not move much within the nation. Nonetheless, there is a substantial out-migration, especially toward the European Union, and in the last years in-migration has increased due to the wars in Ex-Yugoslavia. Many Roma refugees in Serbia come from Kosovo.

23. In Serbia, primary school consists of 8 years: children enroll if they are aged at least 6.5 years at the start of the scholastic year in September. In the lower four grades of primary school students are usually aged 6.510.5 .

24. The only statistically significant difference is in the place of birth: there are less migrant children in treated schools.

25. There is vast evidence on gender gaps in education and their underlying causes. Buchmann, DiPrete, and McDaniel (2008) give a very good review of the literature.

26. In the pre-treatment year, by combining both types of school together, we observe that girls' dropouts are 0.01 - versus 0.006 of boysand their absences correspond to $122 \mathrm{~h}$ - versus 119 of boys. Differences by gender are here not statistically significant.

27. In India, where early marriage is also a common phenomenon, Maertens (2013) shows that perceptions of the ideal age of marriage significantly constrains the education that parents aspire to have for their daughters. Moreover, such aspirations are not sensitive to the perceived returns to higher education. That is not the case for boys.

28. In both rounds the program was advertised in newspapers Politika and Prosvetni Pregled, the last being a newspaper for people working in the education sector; in addition to the advertisement, in 2010-11 schools' directorates-one directorate may be responsible for more than a municipality-informed schools directly.

29. $47 \%$ of schools which applied in 2009 , and did not get selected, did it again in 2010 and two thirds of them got selected in the second year (16 out of 26 schools applying in both years). Among these schools, only two schools, corresponding to $12.5 \%$, is present in our subsample.

30. Schools which applied in 2010 are in the same areas of schools of 2009 and they have almost the same percentage of Roma, on average $13.99 \%$ compared to $13.07 \%$. They are not statistically different $(p$-value $=0.458)$. These are the only information we have on schools which applied and did not get selected. These percentages are different from those reported in Table 1 because in Table 1 we only refer to the first four grades of primary school. Here we have percentages corresponding to all eight grades of primary schools.

31. In both rounds the committee gave priority to schools in the poorest municipalities or with huge Roma settlements (Subotica, Novi Sad, Niš, Kragujevac, Belgrade).

32. This method is similar in spirit to Duflo (2004).

33. We also control for the gender of the assistant, but it does not turn out to be significant in any specification.

34. On average, Roma pupils are absent from school $143 \mathrm{~h}$ (28 days) in a year.
35. Remember that we expect the coefficient of treatment*post in our main regression to be positive for marks (Serbian and mathematics).

36. The average school number of Roma between the two years-preand treatment year-is used to define the two groups. The threshold is here 43 pupils in a school. Our balance tests for the pretreatment year are reported in the Appendix (Table 9).

37. In A.2 we vary the threshold and we find that the effect of the program is stronger, the lower the threshold. This is exactly what we would expect. Remember that this approach delivers the effect of the program on schools for which we define, based on the threshold, that the program is intensive. A lower threshold means that less Roma are in that school and for this reason the program is more effective.

38. For the corresponding references from the education literature see Fryer (2014).

39. We know this fact from informal discussions with assistants. We have also confirmed this fact with survey data for Belgrade schools (only a subsample of schools) for which we have collected additional data. In treated schools, the children with whom the assistant actually worked were, on average, 9.73 years old, whereas children with whom the assistant did not work, were 10.44 years old (Battaglia \& Lebedinski, 2014).

40. For instance, free schools books for first grade or lower repetition rates in general.

41. Dropouts are included in our regressions and have a high number of hours of absences.

42. The obligatory preschool program has been introduced in order to facilitate the transition to school for children from lower socio-economic backgrounds. In the initial years the capacities of preschool institutions were not sufficient to enroll all preschool children. Hence, some children, mainly from poorer families or in rural areas, could not be enrolled in preschool. However, due to the lack in the enforcement of the law, they were allowed to enroll in school also without having attended the compulsory preschool program.

43. On average, in Serbia costs associated with school (books and other school material) correspond to almost $2 \%$ of yearly household income (LSMS, 2003). Based on a survey we conducted in Belgrade, for Roma people these costs account for $6 \%$ of their yearly household income.

44. We calculate the cost for accommodation and stay during the training to be 40 Euros per day plus transport costs of 10 Euros for seven travels. This amounts to 950 Euros. There were 22 days of training and we add additional 14 days for preparation of training and reporting. The cost of trainers is 150 Euros per day and the wage cost is 5,400 Euros. Accommodation, stay, and travel costs of trainers are 1,510 Euros (22 days * 40 Euros +7 travels * 10 Euros). Therefore, the total costs for trainers including their stay and accommodation is 6,910. Dividing this sum with 26 (number of assistants) gives 265 Euros per assistant. The cost of accommodation per assistant (950 Euros) plus training per assistant (265 Euros) adds up to a total cost of the training of 1,215 Euros.

45. 450 Euros * 12 month [wages] * 23 schools/1,268 Roma students $=97.95$ Euros. 


\section{REFERENCES}

Angrist, J. D., \& Krueger, A. B. (1991). Does compulsory schoo attendance affect schooling and earnings?. The Quarterly Journal of Economics, 106(4), 979-1014.

Angrist, J. D., \& Lang, K. (2004). Does school integration generate peer effects? Evidence from Boston's Metco Program. The American Economic Review, 94(5), 1613-1634.

Banerjee, A. V., Cole, S., Duflo, E., \& Linden, L. (2007). Remedying education: Evidence from two randomized experiments in India. The Quarterly Journal of Economics, 122(3), 1235-1264.

Barany, Z. (2000). Politics and the Roma in State-Socialist Eastern Europe. Communist and Post-Communist Studies, 33(4), 421-437.

Basant, R., \& Sen, G. (2014). Parental education as a criterion for affirmative action in higher education. World Development, 64(C), 803-814.

Battaglia, M., \& Lebedinski, L. (2014). The curse of low aspirations: Remedial education and perceived returns to education of roma people. Working papers. Series AD 2014-04, Instituto Valenciano de Investigaciones Económicas, S.A. (Ivie).

Baucal, A. (2006). Development of mathematical and language literacy among roma students. Psihologija, 39(2), 207-227.

Boyd, D., Grossman, P., Lankford, H., Loeb, S., \& Wyckoff, J. (2009). Teacher preparation and student achievement. Education Evaluation and Policy Analysis, 31(4), 416-440.

Brueggemann, C. (2012). Roma education in comparative perspective. Analysis of the UNDP/World Bank/EC Regional Roma Survey 2011 Roma inclusion working papers. Bratislava: United Nations Development Programme.

Buchmann, C., DiPrete, T., \& McDaniel, A. (2008). Gender inequalities in education. Annual Review of Sociology, 34, 319-337.

Cukrowska, E. \& Kocze, A. (2013). Roma, women and men: When gender and ethnic disparities add up. Findings from the UNDP/World Bank/ EC Regional Roma Survey. Roma inclusion working papers. Bratislava: United Nations Development Programme.

Currie, J., \& Thomas, D. (1999). Early test scores, socioeconomic status and future outcomes. NBER working paper 6943. National Bureau of Economic Research Inc.

Domina, T. (2005). Leveling the home advantage: Assessing the effectiveness of parental involvement in elementary school. Sociology of Education, 78(3), 233-249.

Duflo, E. (2004). Schooling and labor market consequences of school construction in Indonesia evidence from an unusual policy experiment. Journal of Development Economics, 74(1), 199-250.

European Union Agency for Fundamental Rights (2014). Poverty and employment: The situation of Roma in $11 \mathrm{EU}$ member states. Technical report, FRA - European Union Agency for Fundamental Rights.

Fryer, R. G. (2010). Racial inequality in the 21st century: The declining significance of discrimination. Handbook of Labor Economics, 4, 855-971.

Fryer, R. G. (2011). Financial incentives and student achievement: Evidence from randomized trials. The Quarterly Journal of Economics, 126(4), 1755-1798.

Fryer, R. G. (2014). Injecting charter school best practices into traditional public schools: Evidence from field experiments. The Quarterly Journal of Economics, 129(3), 1355-1407.

Garaz, S. (2014). Helping the marginalised or supporting the elite? Affirmative action as a tool for increasing access to higher. European Educational Research Journal, 13(3), 295-311.

Hanushek, E. A., Kain, J. F., \& Rivkin, S. G. (2002). Inferring program effects for specialized populations: Does special education raise achievement for students with disabilities. Review of Economics and Statistics, 84(4), 584-599.

Hoxby, C. M. (2000). The effects of class size on student achievement: New evidence from population variation. The Quarterly Journal of Economics, 115(4), 1239-1285.

Jacob, B. A. (2004). Public housing, housing vouchers, and student achievement: Evidence from public housing demolitions in Chicago. American Economic Review, 94(1), 233-258.

Jacob, B. A., \& Lefgren, L. (2004). Remedial education and student achievement: A regression discontinuity analysis. Review of Economics and Statistics, 86(1), 226-244.
Jensen, R. (2010). The (perceived) returns to education and the demand for schooling. The Quarterly Journal of Economics, 125(2), 515-548.

Kertesi, G., \& Kezdi, G. (2011). The Roma/Non-Roma test score gap in Hungary. American Economic Review: Papers \& Proceedings, 101(3), $519-525$.

Kocze, A. (2012). Civil society, civil involvement and social inclusion of the Roma. Roma Inclusion Working Papers. Bratislava: United Nations Development Programme.

Lauer, P. A., Akiba, M., Wilkerson, S. B., Apthorp, H. S., Snow, D., \& Martin-Glenn, M. L. (2006). Out-of-school-time programs: A metaanalysis of effects for at-risk students. Review of Educational Research, $76(2), 275-313$

Lavy, V., \& Schlosser, A. (2005). Targeted remedial education for underperforming teenagers: Costs and benefits. Journal of Labour Economics, 23(4), 839-874.

Maertens, A. (2013). Social norms and aspirations: Age of marriage and education in rural India. World Development, 47(C), 1-15.

Miguel, E., \& Kremer, M. (2004). Worms: Identifying impacts on education and health in the presence of treatment externalities. Econometrica, 72(1), 159-217.

Murnane, R. J., Willett, J. B., \& Levy, F. (1995). The growing importance of cognitive skills in wage determination. The Review of Economics and Statistics, 77(2), 251-266.

Neal, D. A., \& Johnson, W. R. (1996). The role of premarket factors in black-white wage differences. Journal of Political Economy, 104(5), 869-895.

O'Higgins, N., \& Brueggemann, C. (2014). The consequences of cumulative discrimination: How special schooling influences employment and wages of Roma in the Czech Republic. European Educational Research Journal, 13(3), 282-294.

Open Society Institute (2008). International comparative data set. Technical report, Open Society Foundation.

Podgursky, M. J., \& Springer, M. G. (2007). Teacher performance pay: A review. Journal of Policy Analysis and Management, 26(4), 909-949.

Rivkin, S. G., Hanushek, E. A., \& Kain, J. F. (2005). Teachers, schools, and academic achievement. Econometrica, 73(2), 417-458.

Rostas, I., \& Kostka, J. (2014). Structural dimensions of roma school desegregation policies in central and eastern Europe. European Educational Research Journal, 13(3), 268-281.

Sanbonmatsu, L., Kling, J. R., Duncan, G. J., \& Brooks-Gunn, J. (2006). Neighborhoods and academic achievement: Results from the moving to opportunity experiment. The Journal of Human Resources, 41(4), 649-691.

Schultz, P. T. (2004). School subsidies for the poor: Evaluating the Mexican progresa poverty program. Journal of Development Economics, 74(1), 199-250.

Stojanović, J., \& Baucal, A. (2007). Equal Access to Quality Education For Roma: Serbia. In M. Surdu, C. McDonald, \& A. Abdikeeva (Eds.), Equal Access to Quality Education for Roma (pp. 479-618). Budapest: Open Society Foundation-EU Monitoring and Advocacy Program.

Taş, E. O., Reimo, M. E., \& Orlando, M. B. (2014). Gender, ethnicity, and cumulative disadvantage in education outcomes. World Development, 64(C), 538-553.

World Bank (2012). Toward an equal start: Closing the Early learning gap for roma children in eastern Europe. Working papers. World Bank.

\section{APPENDIX A}

\section{A.1 Primary education system in Serbia}

In Serbia, school is compulsory until age 15 . Children enroll at primary school if they are aged at least 6.5 years at the start of the scholastic year in September. Since 2007 the attendance of at least 6 months of a cost-free preschool program is compulsory; in 2010 the length of the compulsory preschool has been extended to 9 months. ${ }^{42}$ 
Primary school consists of 8 years. In the first four grades pupils get one teacher who teaches all compulsory subjects except English, while in the upper four years pupils have one teacher per subject. In the first-grade teachers use descriptive marks; from the second grade on, the range of marks is 1-5 with 1 being the insufficient and worst mark. The marks are categorical. During each semester, a child gets four marks for each subject. Out of the four marks, at least two marks are derived from written tests. The teacher can decide what to use as assessment for the remaining two marks. She could give additional written tests, give marks based on oral examination, homework or class participation (students' motivation and effort are taken into account by the teacher). The final mark at the end of the year is the arithmetic mean of eight marks. If a pupil gets at least one insufficient mark at the end of the year, her teacher can decide whether to let her pass to the upper grade or to ask her to take the retake exam in August. In the last few years the Ministry of Education has suggested that schools reduce repetition rates, especially in the lower four grades.

There are no school fees for primary school, but indirect costs such as books and other school material can pose a considerable cost for some parents. ${ }^{43}$ The Ministry of Education aims at reducing the cost of education and the first graders in 2009-10 are the first generation to receive free text books. The plan is that this generation and all younger generations obtain free school books in the future.

\section{A.2 Sensitivity analysis of the threshold of intensity of treatment}

In the main body of this paper, we examine how the effect of the program varies based on the number of Roma in a school. We split the schools in two equally sized groups based on the number of Roma in the school. We define a dummy 'intensive' which takes value 1 if a school is among schools with less Roma (at most 43 Roma children), and value 0 if a school is among schools with more Roma (more than 43 Roma children). Our balance tests for the pretreatment year are reported in Table 9.

In this section we report how our results change when we vary this threshold. Table 10 shows the results of the intensity of treatment approach for different thresholds.

We rank the schools based on the number of Roma, starting with the lowest, and then divide the schools in 10 deciles. Column (1) of the table reports the results if we set the dummy 'intensive' equal to 1 for schools in the first decile and 0 otherwise. In column (2) we set the dummy "intensive" equal to 1 for schools in the first and second decile, and 0 otherwise, etc. The reported coefficient (intensive * treatment * post) captures the effect of the program on treated children in schools where the program is "intensive". Essentially, going from the left to the right columns we increase the number of schools and thus the number children for which we consider the program to be "intensive". For instance, in column (1) children in schools with less than 16 Roma are considered to be treated. In column (2) this number rises to 23 Roma per school, etc. We expect that the effect of the program drops as we go from left to the right columns and this is exactly what this table shows. The results in Table 10 are only indicative and should be interpreted with caution especially for the lower deciles. For lower deciles we consider only very few schools to be actually treated (in the case of column (1) only one treated school falls into the first decile).

\section{A.3 Cost of the program}

This section aims to give an estimate of the cost of the program and to contrast this program to alternative interventions available to the government. At this early stage of the program it is not possible to provide an estimate of the monetary benefits. Still, we discuss two possible channels through which this program could affect future labor market outcomes and thus, could have a monetary gain. First, the program could raise completion rates of primary school and consequently, the average educational attainment of treated Roma children. Higher educational attainment implies higher earnings (Angrist \& Krueger, 1991). We do not find that dropout rates fall overall, because in the lower 4 grades of primary school the dropout rates are already low. Primary school lasts 8 years and we believe that dropout rates in the higher grade (from 5th to 8 th) are the ones actually affected by the program. A second channel through which the program could affect children's labor market outcomes is through better marks. Several studies (Currie \& Thomas, 1999; Murnane, Willett, \& Levy, 1995; Neal \& Johnson, 1996) have demonstrated a positive relationship between pupils' attainments at school and their subsequent earnings.

The main cost of the program is the (gross) wages of the assistants which amount to 450 Euros per month. In addition to that, in 2009-10, assistants attended seven trainings totaling up to 22 days. Our estimation suggests that the training per assistant had a cost of approximately 1,200 Euros. ${ }^{44}$ The turnover of the assistants in the first year was very low with only two people quitting in that period. This is especially important because it indicates that training costs will not be born each year. Not taking into account the training costs, we calculate that the program cost 100 Euros per Roma student per year. ${ }^{45}$ We know that in Belgrade $53 \%$ of Roma children were actually treated (Battaglia \& Lebedinski, 2014), assuming that the take-up rate was the same also in the whole of Serbia, this yields a cost of 200 Euros per treated child.

There are no cost estimates of other programs in Serbia to which this program could be directly compared. We still discuss two other measures which we consider alternatives to the RTA Program. One possible alternative would be to use professional teachers to give remedial education classes. The gross wage of teachers is in the range of 900 to 1,200 Euros depending on the experience and thus twice the amount paid to the assistants. Assuming that two assistants have at least the same performance as one teacher, the RTA Program is more cost effective. Aside from being less costly, an additional advantage of the Roma Teaching Assistants is that they act as role models for Roma children and this cannot be easily quantified in monetary terms. A second option available to the policy maker would be class size reduction, but this intervention did not yield satisfactory results in some settings (Hoxby, 2000) and is a very costly intervention. Another disadvantage of the class size reduction is that it does not specifically target disadvantaged children.

All of these facts, taken together, indicate that the program is with 200 Euros per child per year not overly costly and that it also performs well with respect to its alternatives.

\section{A.4 Spillover effects-Non Roma pupils}

We can investigate whether this program also affects Non Roma pupils. We employ both econometric strategies and their combination and find that neither absences reduced nor 
marks improved for Non Roma students. The presence of a Roma assistant does not improve Non Roma schooling outcomes. Results are reported in Tables 11 and 12 .

These results, combined together with the previous ones, provide some evidence that the program is succeeding in reducing the gap between Roma and Non Roma children, both in school achievements and attendance.

Available online at www.sciencedirect.com

\section{ScienceDirect}

